\title{
HET SCHOMMELEN IN DE INDISCHE ARCHIPEL.
}

\author{
DOOR
}

Dr. ALB. C. KRUYT.

Het schommelen in de Indische Archipel is van veel betekenis, maar tot nu toe is daaraan weinig aandacht gewijd. Dit heeft er mij toe gebracht om alles wat op schommelen betrekking heeft bijeen te brengen, zowel hetgeen daarover in de literatuur voorkomt, als wat ik door eigen onderzoek ben te weten gekomen. Bij dit onderzoek hebben verscheiden personen mij geholpen, wier namen in het relaas dezer mededelingen genoemd zullen worden, en die ik hier openlijk voor hun hulp dankzeg.

Het vierde deel van Dr. W. Kaudern's „Results of the Authors expedition to Celebes” handelt over „Games and Dances in Celebes”. Daarin spreekt de schrijver ook over het schommelen (bl. 79-85). Het zijn slechts weinige dingen die hier over het schommelen worden genoemd, en deze stelden den schrijver niet in staat om nader in te gaan op de betekenis van dit gebruik in Indonesië.

Wij mogen aannemen, dat schommelen als louter vermaak, zonder enige betekenis, zo niet in de gehele Archipel bekend is, dan toch in het grootste deel ervan. Over het schommelen als kinderspel valt niets te zeggen. Het is zeer wel mogelijk, dat het voortgekomen is uit een vroeger bestaan hebbend ritueel schommelen, maar dit is niet meer na te speuren. Over dit schommelen zal ik het in dit opstel niet hebben.

Naast het schommelen als kinderspel vinden we echter een ritueel schommelen met een magische en godsdienstige zin. De betekenis van dit schommelen wil ik trachten op te sporen. Daartoe is nodig dat het schommelen beschouwd wordt in het verband van het feest of de plechtigheid, waarvan het een deel uitmaakt, want hieruit kan alleen worden opgemaakt wat men met schommelen tracht te bereiken.

Ik zal dus eerst een opsomming geven van alles wat van dit gebruik bekend is. Ik begin met Celebes als het land, waarmee ik het meest vertrouwd ben.

$\mathrm{Bij}$ de Oost- en de West-toradjas is de schommel algemeen in gebruik, 
echter geheel alleen als speeltuig, waaraan niet de minste rituele waarde wordt gehecht. Op alle tijden van het jaar maken jongens en meisjes zich een schommel, gewoonlijk door de twee einden van een rotan aan een vloerbalk onder het huis vast te binden, en daarop wat heen en weer te schommelen. Doet men het buiten, dan wordt een rotan met het ene eind aan een boomtak gebonden, terwijl in het afhangende deel een stok wordt geknoopt, of een lus wordt gelegd; daarop zit of staat het kind en schommelt zich heen en weer. ${ }^{1}$ )

De liedjes die nu en dan bij het schommelen worden gezongen hebben geen andere zin dan om uiting te geven aan de blijdschap, die de sensatie van het schommelen veroorzaakt. Zo tekende ik in het landschap Onda'e op:

Soë ntinimbo-nimbo

De halfcirkelvormige schommel

toedoe ri wawo mbiro;

soë molape-lape

toedoe ri Wawolage. komt neer op het oeverriet ; de schommel die vlug voortschiet komt neer op (het dorp) Wawolage.

In het landschapje Rampi', dat in zekere zin een overgang vormt van de West- naar de Zuid-toradjas (hier heet schommelen mehahoende') vinden wij slechts deze verwijzing naar het rituele, dat men zich alleen in de tijd tussen het einde van de oogst en het ontginnen van de nieuwe sawahs, dus gedurende ongeveer twee maanden, met schommelen mag vermaken. In deze streek hoorde ik schommelende kinderen zingen: Hahoende' loi'a, koeěki-ěki i doë Loemba; ,hang de schommel op, opdat ik de rand van de Loemba-vlakte (in de vallei van de Leboni-rivier) kunne zien”.

Het bovenstaande geldt, zowel wat de wijze van schommelen, als de aard der liedjes betreft, ook voor het oostelijk deel van MiddenCelebes, en voor Zuidoost-Celebes. Nergens in deze streken heb ik iets kunnen ontdekken van een rituele betekenis, die aan schommelen zou worden gehecht.

1) Aan zulk een rotanlijn is de schildpad zich in het bekende dierenverhaal aan het schommelen, wanneer de aap bij hem komt. Deze had al de rijpe pisang opgegeten van de boom, die de schildpad geplant had. Als de aap de schildpad hoort zingen, dat hij van zijn schommel uit de zee kan zien, wil hij ook geschommeld worden. De schildpad vindt dit goed, maar in plaats, dat hij in het eind van de rotan een lus legt, waarin de aap kan zitten of staan, steekt ze hem de doornige liaan in de aars, en geeft het dier tegelijkertijd een hevigen duw. De aap vliegt in de lucht en de rotan trekt hem met zijn dorens de ingewanden uit het lijf, en daarmee de pisangs die hij gegeten heeft. Op deze wijze wreekt de schildpad zich op de aap. 


\section{Schommelen in Pada-Seko.}

De eerste landstreek waar we ritueel schommelen vinden, is het kleine landschapje Pada-Seko, waarvan het nog niet vaststaat, of de bewoners tot het Toradja-volk gerekend mogen worden of niet. Het schommelen is hier een onderdeel van twee feesten, die door en voor de hele stam worden gegeven, en die in wezen weinig van elkaar verschillen : beide moeten dienen om het welzijn en de voorspoed van de stam in alle opzichten te bevorderen.

Het eerste noemen de To Seko merahoeng; bij de Sa'dan-toradjas draagt dit feest de naam van meraoek; dit is uitvoerig beschreven door J. Kruyt (1, 161-172). Daar het merahoeng der To Seko nog niet beschreven is, en het schommelen er een voorname rol in speelt (terwijl het in het Toradja-feest meraoek niet voorkomt), geef ik het verloop der plechtigheid enigszins uitvoerig weer.

De tijd waarop het merahoeng plaats heeft is altijd na de oogst, en het staat niet in onmiddellijk verband met de rijstbouw. Het feest wordt gegeven door den tobara, het stamhoofd, en de plaats waar het gegeven wordt, is zijn woning, die in het $\mathrm{O}$. van het landschapje baroega, in het W. lempo kasitoeroean, ,huis waar men samenkomt", heet. Het feest wordt niet elk jaar gevierd om de hoge kosten die er aan verbonden zijn. Wat onmiddellijk aanleiding geeft dat men besluit het te vieren, ben ik niet te weten gekomen. Men zegt, dat het Hoofd het feest aanricht voor zijn ouders of zijn grootouders, met welke bedoeld zullen zijn de voorouders van de stam, zodat we aan een voorouder- of stamfeest hebben te denken. De bedoeling ervan is dezelfde als die welke ik heb genoemd toen ik het stamfeest op MiddenCelebes heb beschreven (A. C. Kruyt, 2), nam. het algemeen welzijn van mensen, gewassen en veestapel te bevorderen.

Tot inleiding van het feest worden twee varkens geslacht, waarvan aan de goden geofferd wordt, en waarbij aan dezen kennis wordt gegeven wat men voornemens is te gaan doen. De mannen gaan nu buffels opvangen, die op het feest geslacht zullen worden. Zodra twee dieren gevangen en onder de grote woning aan de hoofdpaal gebonden zijn, gaat men ook over tot het maken van de schommels. Daartoe worden om het huis heen stevige staken in de grond geplant, waaraan rotanlijnen worden vastgemaakt, die in een bocht tussen de staken komen te hangen. Zestien van die schommels moeten er zijn, waarvan één bizonder hoog aan de tak van een boom, liefst een waringin, als die in de nabijheid groeit, moet zijn bevestigd. Een grote voorraad 
rotan is bijeengebracht, want zodra een der schommels defect raakt, moet hij dadelijk worden hersteld.

Van nu af aan schommelen de mensen elke dag; op elke schommel zitten vier of vijf mensen, mannen en vrouwen, en twee geven ze op. Het zijn merendeels vrouwen die schommelen, omdat de mannen er op uit zijn om buffels te vangen. Men zingt er ook bij, maar het is mij niet mogen gelukken een schommellied op te tekenen. Wanneer de avond valt, houdt men ermee op, en worden de trommen geslagen.

Intussen gaat men voort met het opvangen van buffels, totdat men er dertien heeft : twaalf mannetjes en één wijfje. Al die dieren worden onder het stamhuis vastgebonden, en overdag geweid. Is het vereiste aantal buffels bijeen, dan gaat men ertoe over alles definitief voor het feest klaar te maken; daarvoor zijn drie dagen nodig. Op de morgen van de dag waarop het feest begint, komen 50 vrouwen en 13 mannen in het stamhuis. De vrouwen zijn op bizondere wijze uitgedost: op het hoofd hebben ze een soort van hoed, die van kralen is gemaakt, en die bovenop met witte kippeveren is versierd. Haar baadje en saroeng (hini) zijn mede met kralen bezet en met koperen belletjes behangen. De mannen hebben fraaie kleren aan; één hunner, de leider, draagt een speer, de anderen hebben ieder een jong nog niet ontvouwen arènblad in de hand. Van de vrouwen draagt één een bord met gepelde rijst, de anderen elk dertien kleine bamboe kokertjes, die met palmwijn gevuld en met een prop van een bepaald kruid gesloten zijn, in de hand. Terwijl deze mannen en vrouwen zich kleden en versieren, mag er niet geschommeld worden.

Als allen gereed zijn, dalen ze uit de woning af, en dan worden ze door den leider der plechtigheid (de man met de speer) in een rij opgesteld: voorop de leider zelf, achter hem de twaalf mannen met het arènblad over de schouder; dan volgt de vrouw met het bord rijst, en achter haar de 49 vrouwen met de kokertjes palmwyn. Met langzame pas en gebogen hoofd lopen ze tienmaal om het grote huis heen, terwijl ze het lied zingen, dat ook op de schommel wordt aangeheven; het lied geldt ditmaal de buffels, beweert men. Daarna gaan ze onder de woning, en worden de aangebonden buffels met rijst bestrooid en met palmwijn besprenkeld. Onmiddellijk nemen twee mannen de lege kokertjes over, en lopen ermee als dwazen tienmaal om de woning heen onder uitbundig gelach van de toeschouwers. Na de ommegangen binden ze de kokertjes aan de hoofdpaal van de woning vast.

$\mathrm{Nu}$ komen vier mannnen, die niet tot de familie der feestgevers 
mogen behoren (mensen uit een ander dorp), fraai uitgedost uit een woning te voorschijn, en snellen op de buffels toe, die ze in een wild tempo doden. Zijn alle dieren dood, dan lopen ze met gezwinde pas achtmaal om het huis heen; bij de achtste maal gaan ze onder de woning door, en snellen naar het huis, waaruit ze te voorschijn zijn gekomen. Als deze mannen weer naar buiten treden, wordt op de trommen geslagen, en komen de schommels weer in beweging.

Een poos hierna verschijnt een man uit het feesthuis met een bamboe in de hand. Op de grond gekomen slaat hij met de bamboe op het houten raam, waarop de onderbouw der woning rust, en roept: „Wie heeft mijn buffels gedood!?” Dan legt hij de bamboe op een balk onder het huis. Deze man wordt gevolgd door een ander die uit de feestwoning neerdaalt met een aarden schaal, waarin damarhars brandt, en met vier bamboetakken. Met dit alles loopt hij viermaal om de woning, en kiimt er dan in. $\mathrm{Nu}$ komt een derde man te voorschijn met de arènbladeren die tevoren zijn rondgedragen; op elk van de buffels legt hij een blad. Eerst nu worden de dieren in stukken gehakt; het vlees wordt vóór de woning op palmbladeren op den grond gelegd. Terwijl vele mannen met slachten bezig zijn, snijden anderen de nerven uit de arènbladeren, en binden deze daarna aan de palen waaraan de buffels gebonden zijn geweest.

De volgende dag worden grote hoeveelheden vlees en rijst gekookt. voor het grote feestmaal. Op deze dag wordt aan de familie, die het feest bekostigt, een plechtigheid voltrokken, die mopadopi „op planken zitten of lopen" heet, en waarvan het voornaamste is, dat degenen, wien het geldt de grond niet mogen aanraken, maar over planken naar het water moeten gaan om daar gebaad te worden. De beschrijving van deze plechtigheid is hier niet ter plaatse; de bedoeling ervan is om door middel van de planken de mensen van de aarde gescheiden te houden, omdat men zich voorstelt dat ze verplaatst zijn in de hemel (uitspansel), het rijk van licht, gezondheid, kracht. Op deze dag ook wordt het vlees rondgebracht in alle huizen. Dit moet naar een vastgestelde regel geschieden; vergist een van de rondbrengers zich erbij, dan wordt hij beboet met een hakmes, een lap katoen en derg.

Op de dag van het mopadopi mag niet meer worden geschommeld; de volgende morgen worden de schommels losgemaakt en weggeworpen. Buiten dit feest mag niet worden geschommeld, en het daarbij behorende lied niet gezongen worden.

Het tweede feest bij de To Seko, waarop geschommeld wordt is het 
moboea', dat door J. Kruyt uitvoerig beschreven is (J. Kruyt 2). Ik kan hier dus volstaan met in 't kort aan te 'geven welke plaats het schommelen in die beschrijving inneemt (bl. 246). Bij dit feest worden enige vrouwen en meisjes gedurende geruime tijd afgezonderd om op het boea'-feest gewijd te worden. Deze vrouwen en meisjes dragen de naam van haliang. Wat met haar gebeurt, vormt een onderdeel van het stamfeest. Bij deze gelegenheid worden eerst op de dag, waarop de buffels geslacht zijn, enige schommels van rotan onder het huis van het stamhoofd aangebracht. De gewijde vrouwen en meisjes (haliang) moeten eerst schommelen (mempio); hierna mag ieder, die wil, meedoen. Vier dagen schommelt men. Na afloop daarvan wordt een buffel geslacht, en de volgende dag wordt alles opgeruimd: de rotan schommels worden onder het huis weggenomen; het feest is afgeloopen. Opmerking verdient, dat bij de Sa'dan-toradjas het ma'boea' en het meraoek gehouden worden zonder schommelen.

\section{Schommelen bij de Zuid-toradjas.}

Wanneer we van Seko naar het Zuiden en Westen gaan, komen we in het woongebied van de Zuid-toradjas. Tijdens mijn bezoek aan het Galoempangse heb ik niets kunnen vinden van een ritueel schommelen, wat echter niet uitsluit, dat het hier of daar toch kan voorkomen. Bij de To Rongkong heb ik het schommelen alleen aangetroffen als vermaak voor de jeugd, dat niet aan enige tijd gebonden is. Beide einden van een touw of een rotan worden aan een boomtak of een vloerbalk vastgemaakt, een plankje wordt in het midden gelegd, en daarop schommelt men zittende of staande; is men alleen, dan geeft men zichzelf op, zit men met meerderen op de schommel, dan geeft een ander hem op.

In het dorp Kanandede in Rongkong worden twee soorten van schommels voor kleine kinderen gebruikt, die een merkwaardige overgang vormen tot de wieg, zooals deze bij enkele Toradja-stammen voorkomt, en waarop ik later terugkom; aan een afhangende rotan of een touw is een houten haak vastgemaakt, waaraan nu en dan een doek wordt opgehangen, waarin het kind wordt geschommeld. Of men legt twee rotan hoepels om een houten bak, en hangt deze aan een balk op; hierin wordt het kind heen en weer geschommeld. Een schommel heet todjang; ma'sintodjang is met elkaar schommelen; pentodjanga heet het touw (rotan) met de houten haak, waaraan de sarong met het kind erin heen en weer wordt geschommeld. 
Van de Toradjas van Mamasa zijn door tusschenkomst van den heer A. Bikker van enige dorpen berichten omtrent het schommelen ingekomen. Slechts van een enkele wordt gezegd, dat dit vermaak daar onbekend is. In dit gebied heet de schommel tio ; mentio ,schommelen”; sintio „met elkaar schommelen”; in Taboelahan zegt men mohian, in Bambang heet de schomel pentjiwoan. In de laatste plaats worden zes stevige bamboestaken van enige meters lengte in de grond geplant, waarvan de topeinden naar elkaar toe gebogen en vastgebonden worden, zodat een stevige stellage wordt verkregen; in de top wordt een dwarshout vastgemaakt, waarover twee rotan ringen worden gelegd; aan deze ringen zijn de touwen of rotans bevestigd, die de schommel vormen; men zit of staat op een plankje: jongens en meisjes doen aan dit vermaak.

Van de meeste plaatsen wordt gezegd, dat het schommelen gedaan wordt in de tijd, waarin aan de kinderen en jongelieden is opgedragen om de rijstvogels uit het veld te verjagen. Men doet het dus in de tijd waarin de vrucht zich zet, totdat de aren worden gesneden. Een magische betekenis van het spel is nergens opgegeven. Alleen vertelde men te Oroboea, dat men in de aangegeven tijd schommelt, omdat deze periode zich kenmerkt door schaarste aan voedsel, daar de oogst van het vorige jaar dan voor het grootste deel verbruikt is. Als de rijstgodin Totibojong de mensen ziet schommelen, krijgt ze medelijden met hen, zegt men, want dan denkt ze, dat de aardbewoners zich uit wanhoop ophangen, omdat ze niets meer te eten hebben; ze zal dan zorgen, dat de aren flink gevuld zijn, zodat ze door de zwaarte overhangen, zoals ook de schommel door zijn gewicht naar beneden getrokken wordt.

Ook bij de naar het Oosten wonende Sa'dan-toradjas wordt in sommige streken geschommeld in de tijd waarin de rijst vrucht zet. Ik tekende dit zelf op van Baroeppoe', Pangala' en Tondok litak. Rotanlijnen, touw van arènhaar gedraaid, en riemen van buffelhuid worden dan met de einden aan boomtakken vastgemaakt. Elk vrij oogenblik, vooral op mooie avonden, zetten jongens en meisjes zich erop neer, en vermaken er zich met schommelen. Er wordt niet bij gezongen, maar men zegt uitdrukkelijk, dat dit vermaak moet dienen om de korrel in de rijst te brengen. Als men met oogsten begint, houdt men op met schommelen (A. C. Kruyt 1, 352).

Ook van het distrikt Koerra in het Rante Paose deelde de onderwijzer mij mede, dat men schommelt in de tijd dat de rijst vrucht zet, „opdat de korrels schommelen (door hun zwaarte) en de aren lang 
worden". De indo' padang of regelaar van de landbouwgebruiken leidt het vermaak in : een liaan wordt aan een boomtak gebonden; men kookt rijst in een bamboe koker, en een hoen wordt toebereid; hiervan wordt aan de goden geofferd. Van het bloed van het hoen wordt wat aan de schommel gestreken, en dan begint de indo' padang te schommelen. $\mathrm{Na}$ hem doen alle dorpelingen het.

Uit de mededeelingen krijg ik de indruk, dat dit schommelen, dat een magische betekenis heeft, niet het echte schommelen is. Dit heeft pas plaats na afloop van de oogst, voordat het nieuwe rijstjaar een aanvang neemt.

Door tussenkomst van de heren Dr. H. van der Veen en $\mathrm{H}$. Pol ontving ik inlichtingen van onderwijzers van enige dorpen. Ook zelf hebben deze heren onderzoek naar het schommelen gedaan, en hun aantekeningen hierover hebben ze tot mijn beschikking gesteld. Het mooiste resultaat van hun arbeid is, dat zij enige liederen of litanieën hebben kunnen optekenen, die bij het schommelen worden gezongen en die ik beneden laat volgen. De inlichtingen zijn van Baroeppoe' (distr. Pangala'), Madandan, beide in het Rante Paose; en Banga (Rembon), Sillana (distr. Mengkendek), Mappa' Balepe', Malimbong, Palesang en Baoe, alle in het Ma'kalese gelegen. Verder van Taba', Penanda (Rante Boea) en Bitoeang, alle in het Rante Paose. Alle gegevens wijze erop, dat in het Sa'dan-gebied het schommelen in nauw verband staat met de rijstbouw; het wordt gerekend tot de aloek pare, ceremonies, die tot de rijstadat behoren. Het duidelijkst blijkt dit uit de schommelliederen, die alle spreken van een welgeslaagde oogst.

In Baroeppoe' wordt schommelen sitirio (eig. ,met elkaar schommelen") genoemd; in andere streken van het distrikt Pangala' zegt men mentirio; weer in andere streken heet het ma'kendong; Madandan heeft de oude vorm van het woord: ma'kaindong bewaard, en Sillanan: ma'kaendong; in Banga zegt men mekendong; hier en daar in het Ma'kalese: ma'gendong. Van het schommelen zelf is niets bizonders op te merken. Evenals elders bestaat de schommel uit een touw (rotan), dat òf met één, òf met beide uiteinden aan de tak van een boom is vastgemaakt. Men hangt de schommel ook graag aan een stevige overhangende bamboestengel; maar als men het volmaakt wil hebben, hangt men de schommel aan een waringin-boom op.

In sommige plaatsen beweert men, dat het schommelen niet aan enige tijd gebonden is ; zó te Taba' en te Penanda (Rante Boea); men zegt hier, dat het een vermaak is van jongens, terwijl ze de buffels 
hoeden. Soms doen ook meisjes het; gezongen wordt er niet bij. Te Penanda vertelde men, dat mannen zichzelf ook wel eens schommelen na het verrichten van enig zwaar werk, bijv. als ze een zware last vervoerd hebben, ,opdat de spieren weer in orde komen”. Men meent dat men door schommelen sterk, dik en groot wordt; het zou dezelfde uitwerking hebben als het masseren der spieren. Op mijn reis in de Toradja-landen in 1920 zei men mij ook in Kesoe', Sa'dan en Baloesoe, dat het schommelen aan geen tijd gebonden zou zijn.

Behalve de opgenoemde gevallen wordt in alle andere streken opgegeven, dat het schommelen plaats heeft na afloop van de rijstoogst, wanneer alle rijst in de schuren is opgeborgen. Het gebeurt ook niet elk jaar. Wil men voor een hele streek een schommelfeest organiseren, dan moeten alle oudsten van het complex het goedvinden. Ze komen bij elkaar om erover te spreken; al zijn er maar een paar oudsten bij, die er zich tegen verzetten, dan heeft het feest niet plaats. Er wordt niet bij vermeld, waarvan het doorgaan van het feest afhankelijk wordt gesteld; zeer waarschijnlijk hangt dit samen met de mate, waarin de oogst geslaagd is; is deze hier of daar minder goed uitgevallen, dan blijft het schommelen achterwege.

Wanneer de oogst in de schuren is opgeborgen, heeft eerst het ma'peong alang, ,,aan de rijstschuur offerspijs te eten geven”, plaats. Naar de beschrijving die de heer Pol hiervan geeft, slacht men twee hoenders : een manoek rame, d.i. een hoen met bonte veren, en een manoek bolong, d.i. een zwart hoen. Het eerste wordt geslacht voor de geesten (deata), het laatste voor de voorouders (todolo). Alle dorpelingen verzamelen zich nu op het erf van het huis van den indo' padang, d.i. degeen die gedurende de tijd dat de rijst te velde staat, zorgt voor de opvolging van allerlei gebruiken (de aloek pare), die de groei en het welslagen van het gewas moeten bevorderen, en een goede oogst moeten verzekeren. Ieder heeft bamboe kokers meegenomen, waarin rijst is gedaan; deze rijst wordt op het woonerf van den indo' padang in de kokers gekookt; zo'n koker met gekookte rijst heet peong, en deze dient tot offerspijs. Het aantal peong is niet bepaald. Is de rijst gaar, en het kippevlees toebereid, dan wordt in elke koker een weinig van het vlees gedaan, en nemen allen hun eigen kokers mee naar huis; hier worden ze aan de rijstschuur gehangen, of bij de slaapplaats in de woning. Dit noemt men ma'bekkak. Vervolgens wordt kleefrijst samengestampt met rijpe pisang of met arènsuiker, en daarvan plakt men kleine hoopjes op verschillende plekken 
tegen de rijstschuur (dit heet toding alang ,,de rijstschuur van stippen voorzien").

Dan volgt nog het ma'biloendak. Een biloendak is een van het jonge blad van arèn- of kokospalm gevlochten peperhuis, waarin rijst met bruine suiker vermengd, is gaar gemaakt. Deze pakjes worden als offerspijs opgehangen aan de petoeo, d.i. de stijl in het midden van de woning, aan de rijstschuur, bij de bron, bij de weg die toegang geeft tot het dorp, op het sawahdijkje, bij pinang- en kokosbomen, bij de buffelstal, en op andere plaatsen. De hele omgeving laat men meegenieten van de nieuwe rijst. Hiermee neemt men definitief afscheid van het rijstjaar, dat verstreken is, en van de geesten, die hebben meegewerkt aan het welslagen van de oogst. Eerst na afloop hiervan mag men overgaan tot het ophangen van schommels.

De schommel bestaat gewoonlijk uit een lange stevige bamboe, aan welks ene einde een dwarshout is aangebracht, dat als haak kan dienen, waarmee de stengel aan de tak van een waringinboom wordt opgehangen, en waaraan hij heen en weer kan schommelen. Aan het benedeneind is nog een stuk hout vastgemaakt, waarop een of twee personen plaats kunnen nemen.

Bij het maken van de schommel wordt aan de goden geofferd, meestal een varken en een hoen, of een van beide. In Banga worden een varken, een hoen en een hond geofferd. In Baoe zijn het drie hoenders. Overal wordt de schommel met het bloed van het geslachte dier bestreken.

In Banga (Rembon) zijn het alleen vrouwen die schommelen: hier wordt onder het schommelen niet alleen gezongen, maar blazen de vrouwen ook op fluiten, toelali genaamd, die aan de bovenzijde van vier, aan de onderkant van twee gaten zijn voorzien. Hier zetten zich soms vier vrouwen en meisjes tegelijk op de schommel. Bij elke groep, die schommelt, moet ten minste één vrouw zijn, die het schommellied kent, want tijdens dit vermak wordt gezongen. Men dankt de geesten dan voor de gekregen rijst, en men vraagt om het volgende jaar nog meer te mogen ontvangen. Het hoofd van het dorpscomplex Tagari vertelde mij, dat de vrouwen zich vroeger wel met goud tooiden, wanneer ze zich op de schommel neerzetten. Mannen en jongens gaan ook wel eens zitten schommelen, maar dit heeft geen beteekenis.

Ongeveer hetzelfde vertelde de parenge' van Manipi' mij: Ieder dorp heeft een schommel. Het staat ieder vrij erop te gaan zitten schommelen. In de zang, die bij dit spel wordt aangeheven, wordt de rijst uit de hemel geroepen, en de rijst van Batoe pela, de plek waar 
de eerste padi in deze streek werd geplant. Gewoonlijk zetten er zich twee of drie personen tegelijk op; ook wel mannen en vrouwen door elkaar (A. C. Kruyt 1, 352-353).

Het schommelen had ten doel, zoals men het in Baroeppoe' uitdrukte, anna sitiro pare anna keisi, ,dat de rijst met elkaar zou schommelen, opdat ze goed gevuld zou zijn". Behalve dat er liederen of litanieën onder het schommelen worden gezongen,worden er in Mappa', Banga, Sillanan, Baoe, Balepe' nog allerlei verlangens t.a.v. van de rijst (oellambe pare) geuit, en wordt ook de wens uitgesproken, dat kippen, varkens en buffels zich voorspoedig mogen vermenigvuldigen, en dat men kinderzegen mag verkrijgen.

Gewoonlijk wordt het schommelen een maand lang volgehouden. In Bitoeang doet men het slechts twaalf dagen. $\mathrm{Na}$ afloop daarvan koken de meisjes rijst in kleine potjes; is deze gaar, dan scheppen ze ze op, en verdelen haar onder de jongens. Meestal zijn de schommels dan al onbruikbaar geworden. Men laat ze aan hun lot over. Of de periode van het schommelen kort of lang duurt, eerst daarna gaat men over tot het in orde brengen van de kweekbedden voor de opnieuw uit te zaaien rijst.

Hier volgen enige schommelliederen of litanieën. Een kort lied werd mij meegedeeld uit Bitoeang, waarvan de vertaling van Dr. $\mathrm{H}$. van der Veen is :

Pare daja sadang kalo', Sae nalemba oeai nabaa lian sadang kalo',

pare tang nakande dena', tang nakaritto balao.
Rijst ginds in 't $\mathrm{N}$. aan de mond van de waterleiding, die komt op de schouder gedragen door 't water, naar de overzijde gedragen door de uitmonding van de waterleiding, rijst die niet gegeten wordt door rijstvogels, die niet aangeraakt wordt door muizen.

Schommellied in Rembon (vert. v. Dr. H. van der Veen).

E, pare daa boettoe Karoea,

to daja to sia'paran, pare dao mai langi', pare masanda roepanna. Nabatoe-batoe dewata, nalappo' to Paloelloengan, natombot takoea boettoe, pada tanete Lakawan.
O, rijst in Noorden op het Karoea-gebergte (met acht toppen i. h. Rante Paosche), de ketens die bij vieren in het Noorden gelegen zijn, rijst, die uit den hemel gekomen is, rijst, wier soorten compleet zijn.

Zij werd als steentjes door de goden gevormd, zij werd opgehoopt door Hem, die 't al omhult, zij werd opgehoopt als ware het een berg, gelijk aan het gebergte Lakawan. 
Nakambio pelambeki, naala pangaloekakki, pangaloekakki kebongi.

Napemengan pong poeangna, napa'kamase-masean, bilanna mapia lambe boro petamba pemala', pemala'ki rekke langi', tanggoekki rekke dewata, le pa'oerande-randeki. To dao Poeang Matoea, deata ambo-amboan, datoe darepe-repean, napoeraimo kandena, napoedimo pamala'ta, pamala'ta lako nene', tanggoetta lako to dolo.

Saidaannamo mai, oerroendoe' lekkona saloe, tiparitikna oeai.

Nalemba-lemba oeai, nabaleo boera-boera.

Moi menammoe Baroeppoe',

ma'karerangmi to Aan,

la ma'dinrika lae lako, la leppang lako-lakoan ? Pare manoka didaja, tang ma'din dikira-kira. Lioe mamma'mi to Koerra, ma'loepi-loepi to Aan, anna lendoe' pare kamban, pare tang ma'rea-rea, takoea boettoe menono', tanete oennola lalan. Anna to mamaa pare,
Zij wordt bereikt door onze gebeden, zij wordt gegrepen door onze offerverrichtingen, onze offerverrichtingen bij avond.

Die de heer is over (alles) geeft haar,

hij betoont daarmee zijn gunst, omdat de smekingen goed zijn en de offergebeden zijn gunst kunnen verwerven, onze offers die ten hemel stegen

onze huldeaanbiedigen omhoog naar de goden, hetgeen wij op de handpalmen aanbieden.

De Heere God in den hoge, de eeuwige godheid, de bestendige vorst, hij heeft een welgehagen in zijn spijze, hij roemt onze offeranden, onze offers aan de voorouders, onze huldeaanbiedingen aan ons voorgeslacht. Meer en meer komt zij hierheen uit het Noorden, de kronkelingen van de rivier volgend, de stroming van het water.

Zij wordt gedragen door het water, zij wordt op de rug met een band om het hoofd gedragen door het schuim.

Ofschoon de lieden v. Baroeppoe' haar verwelkomend tegemoet gaan,

de lieden van Aan haar ontvangen met een offer (dat aangeboden wordt in een mandje v. d. bladnerven v. d. suikerpalm gevlochten), zou zij derwaarts gaan, zou zij daarheen afslaan?

$\mathrm{Zij}$ is rijst die niet bedrogen wil worden, die niet mag misleid worden.

De lieden v. Koerra zijn vast in slaap, de lieden v. Aan zijn in diepe slaap verzonken, en toen gaat de dicht opeen (gegroeide) rijst voorbij, de rijst die de honderdduizenden te boven gaat, als een zich bewegende berg, als een heuvel die voortgaat. Zodat degenen die de rijst dragen, 
eollemba-lemba kinande,

metalloeng lekko sitoeroe'.

Tibattoek oennola lalan.

Saidaannamo mai saoettangana lalanna.

Bambaki napemanoekki.

Sae tongandamo pare.

Pendokap pomomo tondok pettalloek kapalinammo.

Bendan alang karoeatta, sitongat tikoe landa'ta. kamammaranna kinande. Disissing timbomo langan.

Dipakande pia tongan. Ra'pak parande alangta.

Loemmi' papan dao mai naroessoen batoran pare.

Tiba'tik sangkinan rinding, iapi anna mellao.

Anna oettekkai appang natingarapi balasa'. Poendoe dikoko illongna,

makaroën ma'pebaloek. Masiang ma'telang baloek. Tokkonanna ma'pesoeka',

appangna ma'telang baloek, makaroën mapesoeka', dipotammoean tondokna, dipopasa' banoeanna, bilanna meloi lambe. Sarita alli onona, degenen, die het dagelijks voedsel a. e. draagstok dragen,

in drie rijen, die als een gebogen lijn lopen, elkaar volgende voortgaan.

Ordelijk volgen zij de weg.

Zij komt steeds meer uit het Noorden hierheen, meer en meer naar het midden van haar weg.

De toegang tot ons dorp is haar doel.

De rijst is werkelijk gekomen.

Het dorp is al tweemaal gevuld en driemaal reeds is zij overgebracht naar een andere plaats.

Onze acht rijstschuren staan opgericht, onze rijstschuren staan schuin tegenover elkaar, de slaapplaats van het voedsel.

$\mathrm{Zij}$ is tot boven aan opgevuld, als ware ze een bamboekoker met palmwijn, die met een prop is afgesloten.

Haar wordt echt te eten gegeven als a. e. kind.

De dwarsbalk, die de vloer v. d. rijstschuur draagt, breekt.

De planken ervan buigen vanboven door door de druk van de rijst, die er goed geordend op ligt.

De tussenbalken tussen de bewanding raken los, en dan pas gaat zij.

Zij schrijdt over de drempel en de balasa'(?) kijkt tegen haar op.

De buffel met korte horens, die (zo groot is), dat de hand i. d. neus kan worden gestoken, wil in de avond verkocht worden.

In d. morgen verzoekt ze betaald te worden.

De plaats waar zij verblijf houdt, wil uitgeleend worden,

haar drempel verzoekt betaald te worden, in d. avond wil zij uitgeleend worden, haar dorp wordt tot verkoopplaats gemaakt, haar huis wordt tot markt gemaakt, omdat om haar op goede wijze gebeden is. Een sarita (gebatikt lang smal weefsel v. blauwe 
maa' alan baloekanna.

Iato torrona dao,

to titappena ambali', namemba'ka'mo ditikkan,

nalo'dak ditoeat-toean.

\section{Totong dirandean bikka'} nenne' dibaka-bakai, pamoettoetta mettolino, tamba'ta mettaoe mata, taloekkoe ma'loea' doekoeng, oeppopesese rakka'ta, oeppobikkoeng taroenota, oendaka' rokkoak kollong sola taman di baroko. Talandi' soeppoe matoea sola banoe' karoeroengan,

diakka' langan dapo', matoea indoek soeppoe sameloeng,

atta ma'isi pole oeppemallok koettoe'ta.

Atta sirenden rekke tappona limbong, sibakke' rekke matanna oeai, anna pora'ki' lindo masakke, anna pi'pikki' oeai sangpindan, sa'dan sakkori-kori, passakkena Poeang Matoea tambana deata ambo-amboan. Sandaki' mangria pea,

massompo ma'kepak, kleur) is de prijs voor haar (uit d. aar) gevallen korrels, een maa'-weefsel (katoenen tjindai-weefsel) is de betaling v. hetgeen van haar verkocht wordt.

Hetgeen er v. haar boven (i. d. rijstschuur) overblijft,

hetgeen ginds a. d. overzijde wordt achtergelaten, moge zich vermeerderen, wanneer er steeds van genomen worde,

en steeds weer omhoog wippen, wanneer ze omlaag gestort wordt.

Moge steeds een wan onder haar gehouden worden en steeds in korven van haar genomen worden, de kracht van ons aardbewoners, het versterkend middel voor ons mensen, zodat wij bukken een grote zonnehoed op, onze vingers als schopje bezigend, onze vingers als hak gebruikend, zoekend hetgeen in onze hals naar beneden glijdt met hetgeen onze keel ingaat.

Dat wij de hoogste ouderdom mogen bereiken en het harde kernhout v. d. suikerpalm (= een krachtige, taaie ouderdom), zodat wij naar de haard gedragen worden, dat wij oud worden als de suikerpalm en taai blijven als de vezels v. h. dikke einde v. d. bladsteel v. d. suikerpalm, zodat onze tanden weer uitkomen en wij onze knieën als hoofdkussen gebruiken. Dat wij elkaar leiden naar de dijk v. d. waterkolk (v. h. heil), elkaar stuttend naar 't Noorden, naar de bron (van voorspoed), dat $\mathrm{Hij}$ ons besprenkele met gunstrijk gelaat, dat $\mathrm{Hij}$ ons besproeie $\mathrm{m}$. e. bordvol water, water een schaal vol, het heil v. d. Hemelheer het middel tot zegen v. d. eeuwigen God. Dat elk van ons kinderen moge koesteren op zijn schoot, ze moge dragen op de rug en op de heup, 
ma'takea' patomali, pa'kamasena Poeang Matoea. ze vasthoudend op iedere arm, vanwege de goedertierenheid v. d. Hemelheer.

Schommellied in Balepe' (vertaling v. Dr. van der Veen).

Pare kamban dao langi', pare tang ma'rea-rea.

Koepasonglo' dao mai, rappo daja sadang kalo'.

Koesanga bittoën ronno' anna sokko' to mepare.

Dibaleo dikamboetoe',

dilemba ditodo-todo.

Dipalanganno alang, mane sangbassanan langan anna soemakemo appang, makanassak manetena, makoemboen banne malapoe'.
Rijst, die in menigte is boven in de hemel, rijst, die niet gering is in menigte.

Ik doe haar vanuit de hoge neerdalen, tot ginds i. h. Noorden aan de uitmonding van de goot.

Ik meen, dat het neergevallen sterren zijn en het zijn de hoeden v. hen, die rijstsnijden. Wordt ze met een band over 't hoofd gedragen, dan wordt er met de hiel tegenaan geslagen, wordt ze met een stok over de schouder gedragen, dan stoot men er m. d. voet tegenaan.

Ze wordt naar boven de rijstschuur in gebracht, pas is er een laag in omhoog gebracht en ze overschrijdt de drempel, of de nokbalk kraakt, gedrukt door het goed gevulde zaad.

Litanie in Baoe (Ma'kale) bij het offer aan de goden bij gelegenheid van het schommelen uitgesproken (vertaling van Dr. H. van der Veen).

Iko inde nene',

iko inde ampoe padang,

iko inde to matoea, nene' mamase dipemala'i, nene' mario dipekadoai.

Koepasattokkonanmoko mairi', koebato'ko sola nasang, anggammoe to diponene', koepooepoe'mo to dipomatoea, tokkokanmoko sola mairi'. Moeroendoenanmo kande mammi'moe, moe la oentimboe' marasammoe. Moekandemo tawa-tawa, moetimboe' kalasi-lasian.
Gijlieden hier voorouders, gij hier, heer van het veld, gijlieden hier, voorgeslachten, barmhartige voorouders, aan $\mathrm{u}$ wordt geofferd, milde voorouders, gij wordt vereerd.

Ik nodig $\mathrm{u}$ allen uit $\mathrm{u}$ te zamen neer te zetten, ik stel $\mathrm{u}$ allen in een rij, $\mathrm{u}$ allen, die beschouwd worden als voorouders, $\mathrm{u}$ allen, leden van de voorgeslachten, tot den laatste toe richt ik mij tot $\mathrm{u}$.

Gaat tezamen zitten, v. d. eerste tot de laatste toe, dat gij uw heerlijke spijzen in ogenschouw neemt, en uw smakelijk maal nuttigt.

Eet het al lachende, nuttigt het al schaterende. 
Pareopa dilambe, kinande tambai sae.

Rekke naala lambekos,

nakadang pakkoerandekoe.

Pare djadja di Karoea, rekkena to siapparan.

Djadja tongandamo mai. Tang makari'-kari' tongan, sae nalondean bombang,

narakisan boera-boera. Sae indete tondok, ratoe inde do banoea.

Pare tamboen do langi', pare oemba'na roepanna, soenggoen sangda'pa oelinna, sakkaledak soemoelena.

Mane randanna diala, nasilesemo lappo', anna sitoembiringanmo. Misa' to matoea maling napaboea' pangatoran Naaboen dandanan lappo' Dandanan lappo' to Baoe, pangatoran to Lewangra,

soesi sirrit to mamawa, tengan litting malo-malo.
Thans nog wordt om rijst gebeden, het voedsel wordt geroepen te komen.

Moge mijn smeekbede Noordwaarts gegaan haar grijpen,

en mijn smeking met opgehouden handen haar aanklampen.

Rijst in 't N. op het Karoea-gebergte,

Noordwaarts (de ketens), die bij vieren gelegen zijn.

Zij komt waarlijk uit 't Noorden hierheen.

Zij talmt echter niet meer,

zij komt door de golven als in een prauw meegevoerd,

als door het schuim op een vlot gedragen.

$\mathrm{Zij}$ is hier in het dorp gekomen, zij is hier in ons huis verschenen.

Rijst die in menigte is in de hemel, rijst, die in allerlei soorten voorkomt, haar aren zijn uitgekomen één vadem lang, haar lengte is meer dan één vadem en loopt tot aan de oksel.

Pas haar rand wordt weggehaald, de hopen (rijst) vertreden elkaar, zij gaan voor elkaar opzij.

Een oud iemand wordt er verbijsterd van vanwege de (in hopen) geschikte (rijst). ?

De rijen der hopen v. d. lieden van Baoe, de (in hopen) geschikte (rijst) v. d. lieden v. Lewangra, als mieren (zo talrijk) zijn degenen, die haar dragen, als rode mieren.

Tenslotte de Nederlandse vertaling van een schommellied (litanie) uit Ma'kale, door den heer $\mathrm{H}$. Pol.

De rijst, die ik bij mij heb, ons eten dat ik met mij voer, is rijst van de Boentoe Karoea (een hoge berg bij Bittoeang). Rijst die door de geesten was opgeslagen, die ik op de schommel heb geroepen, 
waarmee ik heen en weer schommel, die van ginds komt. De beste heb ik gekozen, waarvan de schil goudgeel is. Waar is het rijstveld van den indo' padang (de regelaar van de landbouwgebruiken), het gedeelte dat voor mijn rijst is afgezonderd, de plaats waar ik mijn rijst uitzaai, de plaats waar ik ons eten plaats. Ze behoeft slechts één nacht in 't water te staan en ze loopt uit. Ze paart zich met rein water, met zachte grond. Welig zijn haar bladeren, haar wortelen verspreiden zich, verspreiden zich als olie, en haar toppen zijn welig. Wanneer haar tijd daar is, als haar tijd vervuld is, is haar dracht goud, lang haar vruchten, alsof het de bloemtros van een sagopalm ware. Een deel is al geel en overrijp het andere. Stuur uw slaven, die gereed staan, die gereed staan om hout te kappen, laat ze een grote peong (bamboe met gekookte rijst) maken, een haan met witte oorknoppen slachten. Zeg tegen uw trouwe slaven, dat zij het rijstmesje klaarmaken. Laat ze verder de plaats waar de gesneden rijst verzameld moet worden in gereedheid brengen. Morgen moeten zij met de rijstoogst beginnen. Ik dacht dat de sterren van de hemel gevallen waren, wijl het de hoeden van de rijstsnijders waren. De hopen gesneden rijst staan op de dijkjes, als grote hopen opgestapelde stenen zijn ze. Maak nog enige peongs klaar en slacht een hoen voor de geesten en offer het met wierook. Laat vervolgens de mensen water sprenkelen rondom de sawah onder het regelmatig uitspreken van: „Rijst en buffels zullen vermeerderen". Zeg dat aan alle inwoners van uw dorp. Wij zullen de rijst van het rijstveld naar huis brengen. Alle mannen van het dorp zijn al vertrokken, gezamenlijk trekken zij op om de rijst te vervoeren, met als plaats van bestemming, de grens van het dorp. De rijst wordt bij hopen opgestapeld, waar wij van onze voorouders af reeds wonen. Op de derde dag zal hij weer peong maken, een hoen voor de geesten (deata) slachten, geurig gras wieroken, waarna wij de rijstbossen kunnen gaan tellen. De opbrengst is groter dan te voren. Zeg nu uw medebroeders, dat zij de rijst naar huis brengen. Overtreffend is het antwoord op het verzoek van hen die schommelen (ze hebben meer gekregen dan ze hebben gevraagd). Het verzoek van de schommelaar wordt rijkelijk gezegend. Voor ons, links en rechts (van ons) zien wij de daken van rijstschuren; ze blinken uit in grootte, de hoeveelheid overtreft het achttal. De plaatsen waar we de rijst moeten opbergen zijn zeer vele; ook de avond is nodig om de rijst op te bergen. Maak voordat gij de rijst opbergt nog een peong en offer een hoen voor de geesten. Overvol zijn de schuren, en ook de grote zijn niet leeg. De kleefrijst wordt op de rekken buiten de 
schuren opgestapeld, en waar geen plaats meer voor is zegt: „Straks zullen wij nog een plaatsje gemaakt vinden, om de rijstschuur heen, waar wij geborgen worden". Zo kan er geregeld zonder veel moeite afgenomen worden, wanneer aan de geesten geofferd moet worden. De nieuwe rijst wordt alle verzameld, zij wenst niet verwaarloosd en bedrogen te worden. Haar roem gaat reeds uit tot de mensen die op verre afstand wonen. Deze rijst kan uit de schuren gehaald worden, wanneer zij gekocht wordt in ruil voor karbouwen, kostbare doeken en goud, vrucht van de handel. Daar er veel mensen de rijst komen kopen, is het aantal draagstokken groot; een omheining om het dorp heen kan ervan gemaakt worden. De touwtjes om de bossen te binden vormen een grote hoop. De deur is gemerkt met het teken van bloed tot reiniging; het aantal rijsthopen vermeerdert steeds; aanmerkelijk veel meer dan gewoonlijk is de hoeveelheid van deze mooie rijst. De varkens eten de afval, vlugger dan gewoonlijk zijn ze groot en vet; groot van omvang; lang worden de slagtanden, zodat de mensen die vuur komen halen, bang worden. Gij, keuken, hebt grote voorspoed, uw haardstenen zijn gewijd, kleefrijst wordt erop klaargemaakt, en buffelmelk wordt erop gekookt. In ons huis zijn mooie rekken, plaatsen voor lepels zijn er vele; en groot is het droogrek voor het eetgerei. Het gat in 't dak is gelijk de neus van een karbouw, het bindgerei voor de atap is (zooveel) als het bindgerei voor de rijst. De kat loopt op de nok van het dak, ze bewaakt het huis, alsook de slaapplaats. In huis vind ik geen plaats meer om te staan of te liggen; links en rechts staan korven; ze zijn gevuld met velerlei soorten weefsels, waarbij nog kostbare, den geesten gewijde doeken, die zeer veel zijn. En ontelbaar zijn de schaamgordels, altemaal feestklederen voor de boea'-feesten, die gebruikt worden wanneer lofliederen gezongen worden.

\section{Schommelen op Zuid-Celebes.}

Wanneer wij verder zuidwaarts gaan naar de Makassaren en Boeginezen, vinden wij een heel oud bericht omtrent het schommelen, waarover de heer R. A. Kern te Leiden mij inlichtte. Hij schrijft: „In 't door Matthes in de Boeg. Chrestomatie II opgenomen gedeelte van de La Galigo komt op bl. 521 v.v. een beschrijving van de schommelplechtigheid voor. $Z \mathrm{ij}$ heeft plaats ter gelegenheid van 't feit, dat Batara Guru zijn zoon, met instemming van landsgrooten, familie en volk, namen geeft. Terwijl de bissu's muziek laten weerklinken en 
gewijde zangen (ada dewata) zingen (niet nader genoemd), wordt de zoon, Batara lěttu' bij name, in den uit den Hemel neergelaten schommel gezet, 300 zoogmoeders en even zoovele kindermeiden stijgen mede in. Aan deze aantallen is geen waarde te hechten. Bij elke gelegenheid worden getalien van volgelingen genoemd om van te duizelen. Batara lěttu' ligt zeven etmalen in den schommel - ook dit is een geijkt getal, al dien tijd gaan de feestelijkheden door, muziek en hanengevechten. Dan begeven zich 's morgens na 't opstaan Batara Guru en echtgenoote naar den schommel, stappen erin en gaan naast Batara lěttu' zitten. Eerst neemt zijn moeder hem op schoot, dan zijn vader, onder groote vreugde, die een wensch voor zijn toekomstig heil uitspreekt. Nu verschijnen ook achtereenvolgens familieleden, ambtsdragers en 't volk; vóór den schommel staande bieden zij geschenken aan. Deze plechtigheid wordt gevolgd door 't op den grond treden van 't wichtje.

„Van tal van aanzienlijke personaadjen wordt in de La Galigo verteld, dat zij als zeer jonge kinderen, doch niet altijd op denzelfden leeftijd aan de schommel-ceremonie worden onderworpen. Daar wordt wel eens bij gezegd, dat de schommel heen en weer wordt getrokken; ook is er wel eens sprake van bepaalde offerspijzen. De plechtigheid wordt niet altijd op dezelfde wijze besproken. Ik herinner mij niet, dat de daarbij gezongen litanieën worden aangehaald (zie ook Matthes $1,63)$ ".

Tot zover de heer Kern. Dr. A. A. Cense te Makassar deelt mij mede, dat in de oudere Makassaarse literatuur van het plaatsen van kinderen op een schommel gewag wordt gemaakt. Het gebruik schijnt trouwens nog algemeen te zijn.

In een mededeeling van een ongenoemden schrijver (Bijdragen, dl. 62,1909 , bl. 707-718) lezen wij van Tappalang (Mandar) : „Het bandanganfeest is bij de kustbewoners niet bekend, doch staat bij de Toradjas zeer in aanzien; hoewel niet onbruikbaar voor andere doeleinden is de belofte tot bandangan toch het meest geschikt om zware bevallingen tot een goed einde te brengen.

„De bevolking wordt op de gebruikelijke wijze bijeengeroepen; in het huis der jonge moeder wordt een rotan schommel opgehangen, waarop zij plaats neemt. Nadat de sanroe bandangan flink is voorgegaan, beginnen eerst de vrouwen en tenslotte ook enkele mannen met bladeren van den klapperboom (bij gemis daarvan ook wel van de rotanplant) in de hand rond den schommel te menariën. Ook met dit 
feest zijn drie dagen en nachten gemoeid, en wordt in de pauzen flink gegeten".

Behalve het rituele schommelen van kleine kinderen heblen feesten waarop dit gedaan wordt plaats na afloop van de oogst. In verschillende van zijn geschriften vermeldt Dr. B. F. Matthes dit gebruik (Matthes 1, 12-13; 2, 348, s.v. todjang; 3, 1; 4, 21; 5, 150). Deze mededelingen komen alle op hetzelfde neer en geen is nauwkeurig genoeg om ons een juiste voorstelling van de plechtigheid te kunnen maken. Ik geef hier de meest uitvoerige beschrijving; deze komt voor in het jaarboekje Celebes van 1865 :

„In oude en soms ook in latere tijden bestond er in Boelo-boelo en andere Boegineesche landen aan de hoven een gewoonte om nu en dan een schommelfeest te geven (taro-pere); en dat was dan bijna de eenige gelegenheid voor de prinsen om kennis met de jonge prinsesjes te maken, dewijl die zich anders bijna nooit lieten zien. Bij gelegenheid van dit feest gingen de jeugdige schoonen een voor een op de schommel of pere zitten. En wanneer er dan onder de prinsen één was, die zich door de bekoorlijkheden van een prinsesje aangetrokken voelde, zoo nam hij zijn bij het heft van de kris ingestoken zakdoek, en bond dien van voren aan de schommel vast, als 't ware uit vrees, dat het meisje anders onder het schommelen voorover storten en zich bezeeren mocht. Deze teedere bezorgdheid werd dan als een soort liefdesverklaring beschouwd, en wanneer de jonge man in den smaak viel, door een huwelijk achtervolgd. In tegenwoordige dagen treft men dit gebruik ook nog van tijd tot tijd in de gouvernementslanden, bijv. te Bantaeng en elders, aan, en wel bij gelegenheid van het spinfeest, dat ter eere van de jonge meisjes, die mee hebben helpen spinnen, gegeven wordt" (Matthes 5, 150).

Van een bezoek dat Matthes aan Segeri bracht, vertelt hij o.m.: „Het feest van het stampen der jonge padie duurt .... drie dagen en nachten. Alsdan blijft de hemelsche ploeg (d.i. de ploeg van Poewa Longgi, de man, die de eerste padievelden in het land van Segeri heeft aangelegd, welk werktuig uit de hemel neergedaald zou zijn) binnen de kamer, doch ook deze feestelijkheid heeft ten huize van den Anregoeroe (die de heilige ploeg bewaart) plaats. Bij die gelegenheid moet het schommelen een van de voornaamste amusementen der schoone sekse van Segeri zijn" (Matthes 4, 21).

Gaan we nog meer naar het Zuiden, dan vinden wij het schommelen vermeld op het eiland Saleier: „Andere zeer in zwang zijnde volksvermaken zijn de spin- en schommelfeesten. Op beiden worden 


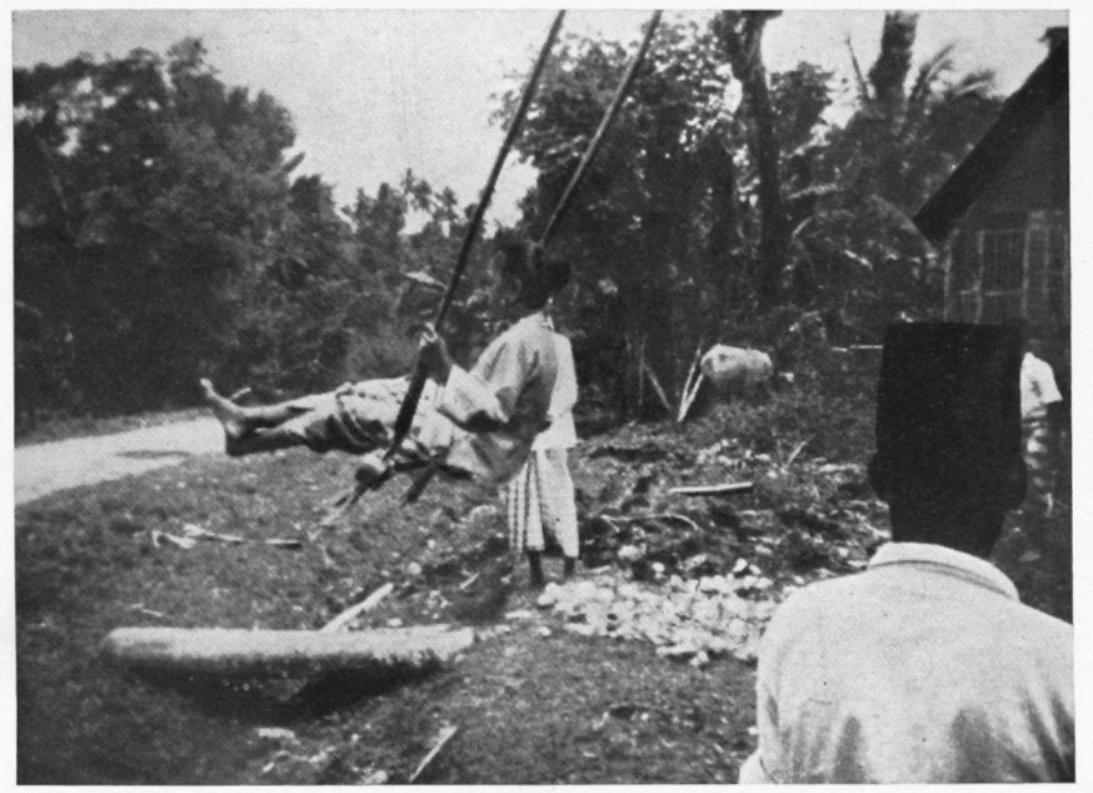

Schommelen op Saleier.

Foto Dr. C. Nooteboom. 
tal van huwbare meisjes genoodigd, waarvan het gevolg is, dat vele jongelingen, genoodigd of niet, hunne opwachting komen maken, allen in feestgewaad. Gedurende het spinnen worden minneliederen gezongen, die doorgaans den grondslag leggen voor een aanstaand huwelijk. - Evenzoo bij het schommelen; het meisje dat door een jongeling geschommeld wordt - toèng - is doorgaans zijn uitverkorene, hetgeen hij haar te kennen geeft door het bewijzen van onnoemelijk kleine beleefdheden" (Engelhard, 313).

Dr. A. A. Cense te Makassar was zo vriendelijk mij zijn aantekeningen over het schommelen op Zuid-Celebes ter publicatie af to staan. Ik laat ze hier volgen,

"In enkele kampongs van de adatgemeenschappen Segeri, Ma'rang en La'bakkĕng (onderafd. Pangkadjene) worden soms schommelfeesten georganiseerd door leden van een bepaald geslacht.

„Toevallig woonde ik 17 November 1935 in de kampong Laikang van de adat-gemeenschap Ma'rang een dergelijk feest bij, dat gegeven werd ter gelegenheid van een huwelijk. Van een der familieleden van de bruid vernam ik het volgende:

„Ongeveer zeven generaties geleden woonde in Bone lalě' bata een anregoeroe pakkalawing epoe' (hoofd der sirihdoosdragers), genaamd La Sěllomo, met zijn vrouw, Iněkki' geheeten. Toen het huwelijk langen tijd kinderloos bleef, dẹden zij de gelofte, dat zij, als een kind zou geboren worden en het zou een jongen zijn, hem op een schommel zouden zetten. Inderdaad ging hun wensch in vervulling: er werd een zoon geboren en zij deden hetgeen zij beloofd hadden. Sindsdien achten alle nakomelingen van dit echtpaar zich gebonden om eveneens overeenkomstig de gelofte van hun voorouders te handelen. Bij elke ceremonieele handeling (gaoe') in het leven der kinderen, bij tandenvijlen, besnijdenis en bij huwelijk wordt dè persoon, voor wie de plechtigheid geldt, op een schommel gezet. Naar men zeide, zouden ongelukken de familie treffen, indien het schommelen werd nagelaten, terwijl overigens de bij rang en stand van de betrokkenen passende gebruiken wel in acht zouden worden genomen. Zoo is het makěrrě (pěmali) bij de feestloods een statietrap of liever loopplank (sapana) aan te brengen, wanneer er niet geschommeld wordt. Omgekeerd mag er niet geschommeld worden, als de sapana is achterwege gelaten, en slechts een gewone trap met treden is gebruikt.

„Het schommelen heeft plaats vóórdat men met de ceremonieele handelingen (tandenvijlen enz.) begint; bij het huwelijksfeest (a'bottingěng) echter wordt het bruidspaar eerst na het ceremonieele bad 
op de schommel gezet. De schommel (todjang of pere') wordt op een sawah buiten de kampong opgericht. Daartoe zet men twee stevige palen (alliri), ongeveer negen meter lang, in den grond, en aan de deze palen verbindende dwarsbalk (arasĕng) wordt met een paar lange touwen het zitplankje (toedangěng) opgehangen. Degene, die daarop plaats neemt, krijgt voor de buik een plankje, wakkang genaamd. Het geheele gevaarte wordt door vier bamboe staken (pattoempa') gestut. Bij den voet van elk dezer pattoempa's vond ik bepaalde bladen en planten in den grond gestoken: bij de linker vóórpattoempa' een jong klapperblad (marasoea) geknipt in reepen, die tot twee mandjes waren gevlochten, bij de rechtsche een pinangbloemtros (madjang); bij de twee achterste stutten was een klapperbloemtros (tobo kaloekoe) neergezet. Al deze planten waren afkomstig van de z.g. warowo oeaë, de pot met water en geneeskrachtige kruiden, dat bij 't baden van het bruidspaar wordt gebruikt. Boven in den schommel hing nog een antjĕ' (offermandje) met sirih (ota).

„Het feest begon met het in optocht naar buiten brengen van bruid en bruidegom, die beiden volledig waren uitgedost. Gezeten op de schouders van familieleden werden zij gebracht tot bij den schommel, waar zij op een matje plaats namen. Naast hen werden door de bruidsmoeder (indo' botting), in dit geval een kawe-kawe, een in vrouwenkleeden gestoken mannelijken doekoen (sanro), nog een mandje met magische geneesmiddelen (een z.g. bakoe' pa'boera) en een schaaltje met een tjoeriga en een lae-lae neergezet (dit zijn voorwerpen behoorende tot de z.g. pa'doekka setang - duivelbanners zie de afbeelding bij Matthes: Over de Bissoe's etc., plaat I, fig. 6, 15 en 1). Een oude vrouw zong onderwijl, daarbij telkens de ana' běttjing (ook een duivelbanner) tegen elkaar slaande. Toen nam een vrouw gekleed met een doorschijnend baadje (badjoe rawan) op den schommel plaats; voordat zij echter ging schommelen, werd eerst nog een antjě (offermandje) met allerlei soorten gebak (beppa to-riolo „koekjes der voorouders”) en vervolgens ook de schommel zelf met bloed van een jong haantje besmeerd (ritjera'), waarna de antjĕ boven aan de dwarsbalk werd gehangen.

„Toen begon het schommelen. Dit ging zóó : twee mannen hielden een strak gespannen stuk wit goed (widang) voor de wakkang, trokken dan den schommel achteruit en sprongen vervolgens terzijde, wanneer dan de schommel naar voren kwam, pakten ze vlug de widang weer op en gaven ermede weer een zetje tegen de wakkang. Tot driemaal toe werd de schommel met deze widang opgezet (rirere), 
vervolgens gebruikte men daarvoor een touw. Vooral wanneer de schommel vaart gekregen heeft, is er een groote behendigheid vereischt om te zorgen, dat het touw niet boven of beneden de wakkang terecht komt, hetgeen voor de persoon op den schommel zeer pijnlijk kan zijn.

„Na haar nam de bruid samen met een andere vrouw, die haar op de schoot hield, plaats op de toedangěng, waarop beiden eenige malen zachtjes heen en weer werden geschommeld. Vervolgens werd de bruidegom geschommeld, en na hem nog een vrouwelijk familielid.

„Dcze vier personen kregen tijdens het schommelen allen een pakje rijst in pisangblad gewikkeld op den schoot; wanneer dit op den grond viel, werd 't vlug door de kinderen opgeraapt en opgegeten. Hetzelfde geschiedde met den inhoud van de opgehangen antjě', die door het schommelen ook op den grond gevallen was.

„Nog enkele meisjes en vrouwen, allen met een sjaal om 't midde! gebonden om te voorkomen, dat haar baadje zou opwaaien, kwamen vervolgens aan de beurt; echter werd bij 't opzetten van den schommel geen widang meer gebruikt.

„Naar men zegt, wordt soms door jonge mannen, die vues op een meisje hebben, ten teeken van hun genegenheid een wit zakdoekje voor haar aan de touwen van de schommel gebonden.

„Tijdens dit schommelen, dat door muziek van twee trommen, een pali-pali en een gong werd begeleid, bleven bruid en bruidegom op het matje zitten, de bruid zooals betaamt met terneergeslagen oogen.

„Na afloop werden zij weer op de schouders der familieleden naar huis gedragen".

Dan volgen enkele korte aantekeningen van denzelfden geleerde, die hij maakte op een tournée in het gebied van Bonthain en Boeloekoemba :

„In Bonthain wordt geschommeld na den oogst, ook wel in geval van ziekten. Men noemt het schommelen een pa'balle ,obat”.

„In het Patoentoeng-gebied bij Kadjang kent men hier en daar het gebruik om te schommelen tijdens den rijstoogst.

„In kampong Kompasa', dichtbij Loka, op de zuidelijke helling van den Lompobattang, deelde een oude man mij mede, dat in zijn jeugd zijn vader eens tijdens een ziekte een gelofte (kana) had afgelegd om na genezing een schommelfeest te organiseeren; daarbij had zijn vader zelf geschommeld.

„In Malakadji (in het bergland van Goa, dichtbij Loka) kent men 
eveneens schommelfeesten bij de inlossing van een gelofte; ook daar wordt zulks als pa'balle beschouwd.

„In de adatgemeenschap Tanaberoe (onderafd. Boeloekoemba) wordt in de ouderwetsche kampong Tarampang nog geschommeld; men doet het daar om ziekte af te weren, wanneer het land ,bambang”" (heet) is. De schommelende vrouwen zijn daarbij in feestkleedij gestoken (makelompo).

„Ook in Bone wordt na den oogst geschommeld”.

Ook de volgende berichten over het schommelen op Boeton en de Toekangbesi-eilanden zijn afkomstig van Dr. Cense: „Bij de dichtbij de Kraton Bolio wonende Katobengke, en ook in de kampong Bataoega, wordt op groote schommels (Bolio: tea) geschommeld gedurende den tijd tusschen het uittrekken van de oebi uit de tuinen (ongeveer Augustus) en het begin van den regentijd. Door de volwassenen wordt vooral 's avonds bij lichte maan geschommeld, door de kinderen ook wel overdag.

„Op het eiland Kaledoepa (behoorend tot de groep der Toekangbesi-eilanden) is schommelen hèt spel, waarmee jonge mannen en meisjes zich gedurende den geheelen drogen tijd vermaken. De schommels (in de taal van Kaledoepa : boënga) zijn opgehangen aan hooge stellages. Het opzetten geschiedt door twee mannen, die staande op steunsels aan de palen iets boven den grond aangebracht, telkens de touwen achteruit trekken".

De mededelingen uit Soppeng en Enrekang zijn afkomstig van Dr. Cense's medewerker, de heer Noeroeddin Daeng Magassing. Ze zijn in het Maleis opgesteld, en ik geeft er het belangrijkste uit weer. De berichtgever woonde een schommelfeest te Pattodjo, ongeveer 9 K.M. van Watasoppeng gelegen, bij. De schommelstelling was gemaakt van twee grote kapok-stammen, die naar elkaar overhelden. Vrouwen en meisjes werden geschommeld, en uit de omstandigheid, dat dezen geen aarzeling of vrees toonden, maakte de heer Noeroeddin op, dat ze het schommelen gewend zijn.

De heer Noeroeddin vertelt dat op 15 Februari 1936 het dorpshoofd van Bila hem geleidde naar de pattoenoengnge ri Mattiropole. Pattoenoeng is de verbrandplaats, waar de asch van de vroegere vorsten in potten is begraven. Deze plek is vrij klein. Matoa Bila vertelde, dat vroeger de bewoners van Soppeng elk jaar bij duizenden hier samenkwamen, na afloop van de rijstoogst; men bracht zijn eigen proviand mee. De leden van de Adat kwamen er ook. Daar 
werd een schommel opgericht. Het waren meestal fraai geklede meisjes, die geschommeld werden. Er werd ook met de bal gespeeld en gedobbeld. Drie dagen lang duurde het feest. De bissoe (heidense priesteressen) brachten offers, en haar leidster, de poeang matoa, werd door een geest bezeten. Op de laatste dag ging een als bruid uitgedoste maagd op de schommel zitten; zij werd ina todjang ,moeder van de schommel" genoemd.

„Als men met schommelen zal beginnen, wordt eerst rijst van vierderlei kleur (wit, zwart, rood en geel) aan de voet van de schommel gelegd; dit heet pattoana; wierook wordt er gebrand, en dan wordt een meisje, dat in het wit gekleed is, bewierookt; zij draagt de naam van ina todjang ,,moeder van de schommel”. De bissoes dansen om de schommel heen; dit heet naaloe' bissoe ,,door de bissoe vereerd". Daarna wordt de ina todjang door de leidster op de schommel gezet, en twee-, driemaal heen en weer geschommeld,waartoe de schommel aan een zijden doek getrokken wordt. Als ze van de schommel is afgegaan, gaan de andere meisjes er om beurten op zitten, en worden door twee mannen zo hoog mogelijk opgegeven; dit wordt drie dagen lang gedaan. Op de laatste dag wordt een buffel geslacht, waarvan een algemene maaltijd wordt bereid. De ina todjang, die als een prinses is uitgedost, wordt dan weer op de schommel gezet; zij krijgt dan de naam van pappettoe todjang ,,de afbreekster van de schommel", want als zij van de schommel afgaat, wordt deze afgebroken".

Soms doet iemand de gelofte een schommelfeest te zullen houden. Er wordt dan bij de schommel een hut gebouwd. De bissoes doen er in optima forma dienst, waarbij mannelijke en vrouwelijke bissoes overeind staande hoofddoeken op het hoofd, krissen om de zijde en vrouwen-armbanden om de polsen hebben. Als ze de schommel hebben ingewijd, gaan ze in de hut haar litanieën zitten zingen; dit heet makkelong dewata.

In Enrekang heeft het schommelen op dezelfde wijze plaats als in Bone; het heet hier mondoa'. Wanneer de palen (meestal pinangbomen) voor de schommel worden geveld, wordt een buffel geslacht. Ook hier wordt wel eens de gelofte afgelegd een schommelfeest te houden; maar daartoe zijn alleen rijke mensen in staat, die veel buffels bezitten. Lieden van adel maken ook een schommelfeest als ze er zin in hebben, soms wordt het ook gedaan bij het einde van de grote vasten.

Voordat we Celebes kunnen verlaten, moet ik het schommelen nog 
van de Minahassa vermelden. Volgens Graafland (I, 282) is het een dagelijks vermaak; de schommel bestaat uit een touw, waarvan de beide uiteinden aan een boomtak worden vastgemaakt. In Tondano heet het spel matatingkajong; in Sonder matambereng; elders weer anders ; zo bij de Tontemboan tatatoejan, ook tatamberenan, patamberenana (Tontemboansch-Nederl. Wdbk., i.v. tajoe en tamberen).

\section{Schommelen op Borneo.}

Ook onder de verschillende Dajak-volken heeft het schommelen plaats bij plechtige gelegenheden. We wenden ons eerst naar Koetei, vanwaar we twee berichten over ritueel schommelen hebben. Om met het oudste te beginnen, deel ik mee wat Carl Bock (110-111) ons daaromtrent vertelt. Deze reiziger beschrijft een feest dat hij bijwoonde, en dat gegeven werd door den Sultan van Koetei. Het zou moeten dienen om den duivel te verdrijven. Het terrein van de feestelijkheid was de overdekte hof van het paleis, waarmee vermoedelijk bedoeld is wat op Java pendapa heet.

Van het midden van het dak hing een zware bos gras af, die tot aan de grond reikte; daaromheen dansten vier Dajaks die op bizondere wijze uitgedost waren. Wanneer ze moe waren van hun ronddraaien, ,they sat down on a swinging seat - a long flat board with the ends carved to represent the head and the tail of a crocodile - that hung from the roof". Toen ze uitgerust waren, liepen ze om een soort van altaar, en nadat ze dit enige malen hadden gedaan, ,they went down on hands and knees making a grunting noise and crept around it as if seeking for something". Gevraagd wat dit te betekenen had, zei men naar den duivel te zoeken; ze vonden hem en joegen hem weg.

„This episode satisfactorily terminated, three hideous old women, dressed in red cloth sarongs, faded from frequent use, were brought in with great pomp, carried on the shoulders of Malays, and took their seats amidst great silence on the large swinging bench in front of the altar. Not a sound escaped the great crowd, who regarded the business as most serious. The old women then began to swing themselves", terwijl ze zich met Chinese waaiers koelte toewuifden. Middernacht werden enige schoten uit geweren gelost, waarbij de bevolking kreten uitstootte. Gedurende drie nachten werd dit toneel herhaald. „Besides the three old women there were three younger ones, and all the six were furnished with a bow and arrow, at the end of 
which were fastened from one to six wax lights. These fiery arrows were each shot several times against the altar, the lights of course being extinguised each time. The object of this was to drive satan away".

Het tweede bericht is van den toenmaligen resident van Koetei S. W. Tromp $(87,89)$. In een aantekening op zijn uitgave van de Salasila van Koetei vertelt hij iets van de ,belijans" of sjamanen der Dajaks, waarbij schommelen te pas komt. „Voor de aanroeping hebben de ,belijans” een groote bos aren- of pinangbladeren gebonden rondom een houten spil, die op een paal kan draaien; dit is hun altaar ,seriding" geheeten.... Somber dreunende loopen ze rond de langzaam draaiende ,seriding”, de eene hand aan de blaren daarvan houdende, met de andere hand de kralen hangers (die van hun hoofddoek afhangen) bewegende; zij gaan hiermee voort tot zij de ,sangijang" in zich opgenomen hebben. Dan gaan ze zitten op een lange plank, aan welker ééne uiteinde een krokodillenkop ruw uitgesneden is; deze plank is aan twee touwen opgehangen en de belijans zorgen er voor, haar in schommelende beweging te houden".

Er is nog een offerstelling, glanggang geheten, waarop de sangiangs neerdalen om de dewa (vrouwelijke belians) te bezielen, die eveneens op een schommelende plank zitten, die in een slangenkop eindigt. Ze schommelen zo lang tot de sangiang in haar is gevaren.

Opmerking verdient wat de Schrijver erbij voegt, dat de belians in de heidense Bahau-streken, waar ze ,běhabei” heten, dit schommelen niet kennen.

Dat schommelen bij verschillende Dajak-stammen tot de onderdelen van een algemene plechtigheid behoort, die tot genezing van zieken dient, vinden we uitvoerig meegedeeld door Rev. J. Perham. De omstandigheid dat de manang of sjamaan dit doet is van belang, en daarom is het nodig, dat ik even aanhaal wat Perham van dezc mensen zegt (102): ,Women as well as men may become Manangs. In former times, I believe, all Manangs on their initiation assumed female attire for the rest of their lives; but it is rarely adopted now, at least on the coast districts; and I have only met with one such. If you asked the reason of this strange custom, the only answer forthcoming is, that the spirits of the deities who first taught Dyaks the knowledge of the powers of Manangism, gave them an injunction to assume the woman's garb. It will be observed that most of the beings mentioned or invoked by Manangs are addressed as „Ini” "Grandmother", which perhaps implies that all the special deities of 
the Manang world are supposed to be of the female sex, and to be consistent with this belief, it might have been deemed necessary for the Manang to assume the outward figure and the dress of his goddess". Waarom de tussenpersonen tussen mensen en goden gewoonlijk vrouwen zijn, heb ik voor de Toradjas trachten aan te tonen in mijn opstel over het stamfeest (A. C. Kruyt 2). Bij de Dajaks zijn het dus oorspronkelijk alleen vrouwen die schommelen.

Nadat Rev. Perham een beschrijving heeft gegeven van de algemene gang van het belian of de plechtigheid waarbij de manang de ziekten verdrijven, geeft hij enige bizonderheden over de ,takken”, die bij dit werk toepassing vinden, want niet elke ziekte wil op dezelfde wijze behandeld zijn. Onder de bizonderheden, dit zijn de handelingen die de manang bij hun werk verrichten, noemt hij op:

„2. Berua „,swinging”. The Manang sits in a swing and rocks himself with the idea of knocking or driving away disease" (Perham 97). Het berua, zegt de Schrijver erbij, behoort onder de meest toegepaste plechtigheden.

„5. Bepancha „making a pancha”. A Pancha is a swing erected on the "tanju" or platform in front of the house, and the Manang swings in it, as in "Berua”, to express the action of ,kicking away”" the malady. An offering to the spirits is laid on the platform" (Perham 98).

„9. Betiang Garong „Making a post of or for the Manes”. A swing is constructed on the roof-ridge of the house, and the Manang performs his swinging there. An offering is also made on the ridge" (Perham 98).

„13. „Ninting Lanjang”. Two swings are constructed along the whole length of the house, and the swinging farce is gone through in another form" (Perham 100).

Uit deze mededeelingen blijkt duidelijk dat schommelen een belangrijk onderdeel uitmaakt van de plechtigheden der sjamanen, dus de lieden die het contact tussen hemel en aarde bewerkstelligen, want de belian is in voortdurend verkeer tussen mensen- en godenwereld.

Ook bij de Malanau-dajaks schommelen de sjamanen veel. Sir Spencer St. John, aangehaald door Ling Roth (I, 284), vertelt dat de sjamaan zich onder muziek laat schommelen, totdat hij ongevoelig van de schommel afvalt. Zo deed ook een oude vrouw, die hierbij het medelijden van de goden inriep.

Maar ook bij andere gelegenheden maken de Malanau-dajaks van schommels gebruik. Ling Roth zegt (I, 37) : „Sir Spencer St. John 
says of the Malanau swings: In front of the houses were erected swings... One about forty feet in height was fastened to strong poles arranged as a triangle, and kept firm in its position by ropes like the shrouds of a ship. From the top hung a strong cane rope with a large ring or hoop at the end... For the younger children smaller ones were erected, and it required courage and skill to play on the larger".

Het is duidelijk dat we hier niet met een sjamanen-plechtigheid te doen hebben, en dat allen, groot en klein, zich met schommelen vermaken. Op een andere plaats spreekt Spencer St. John van schommelen in verband met het landbouwfeest. Zo vertelt hij van een feest bij de Land-dajaks, dat midden in de oogsttijd valt, en dat vier dagen duurt (St. John, 182, 183). Hiervoor is een grote hut buiten het dorp opgericht; het terrein wordt verlicht door grote vuren; een offertafel is bij de hut gemaakt, en daaromheen dansen enige in feestkleding uitgedoste mannen en vrouwen, van wie enkelen brandende kaarsen in de hand dragen, anderen houden koperen presenteerbladen vast, waarop offers van rijst liggen; weer anderen hebben gesloten manden bij zich, waarvan de inhoud verborgen wordt gehouden voor de niet-ingewijden. Van een van de hoge bamboe staken, die zich in de hoeken van de offerstelling bevinden, hangt een lange smalle strook wit katoen af. Op een gegeven ogenblik lopen ouderen en sjamanen op dit katoen af, grijpen er het ondereind van beet, en onder het oorverdovend geluid van trommen en gongs ,,begin dancing and swaying themselves backwards and forwards, and to and fro. An elder springs on the altar, and begins violently to shaken the tall bamboos, uttering as he does so shouts of triumph, which are responded to by the swaying bodies of those below; and amid all this excitement, small stones, bunches of hair and grains of rice, fall at the feet of the dancers, and are carefully picked up by watchfull attendants. The rice is the soul sought for, and the ceremony ends", doordat verscheiden sjamanen flauw vallen en door haar jongere zusters worden bijgebracht.

Een ander bericht over schommelen in verband met de rijstbouw bij de Malanau-dajaks hebben we van Sir James Brooke, angehaald door Ling Roth (I, 367-368) : „At Mukah as we were passing down we saw many swings erected and large numbers congregated them, who were swinging and yelling with every demonstration of lighthaertedness and freedom. These swings consist of a stout single rattan attached to a high derrick, having guys to keep it from swaying in 
to and fro; the end of the rattan has a loop within a few feet of the ground; a ladder is erected at the distance at which the end of the rattan describes its circle. A man then takes the loop up the steps, places its foot in it, and swings of from the top of the ladder, holding by his hands to the rattan. On its returning another man jumps from the ladder on the swing, sometimes two at a time; and this goes on as ten or twelve swinging together, clinging on by each other's arms of legs. While in this position they strike up a monotonous dirge, beseeching the spirits for a plentiful harvest of sagu and fruit and a successful fishing season. They often get bad falls during the amusement”.

Een ander bericht waarin gesproken wordt van het gebruik van een schommel bij een plechtigheid tot genezing van een zieke, vinden we bij de Doesoen-dajaks (te Wechel, 46). Eerst doet de balian of sjamaan allerlei werk om de ziektegeest te verdrijven, maar in de tweede nacht van het feest moet de levensgeest, amiroë, teruggehaald worden. Als een luchtgeest hem gevangen houdt, gaat de balian hem zoeken met een miniatuur vaartuig, aan de mast waarvan een houten vogel is gehangen; de vogel draagt het schip door de lucht. Een hondje van hout, wau-wau, wordt aan de ra van de mast gebonden: dit dier voert het schip door het bos. De balian vangt de amiroë dan in een kleine doos, en wrijft hem samen met wat olie op een schaaltje. Die olie wordt de kranke op het hoofd gestreken, en daarmee komt de ziel in hem door de fontenel.

Dan gaat de schrijver voort: „Hält ein Buschgeist amiroë gefangen, so wird ein Brett gebraucht, auf dem eine Schlange gemalt is, während vorn ein hölzerner Schlangenkopf angebracht ist. Das Brett heisst papan ajon-ajon = Pendel oder Schaukelbrett. Diese papan - mit zwei Schnüren an der Decke fest gebunden - wird von der mandong (een vrouw, de helpster van de balian, die de geestentaal welke hij spreekt, vertolkt) ins Schaukeln gebracht, nachdem der Balian sich darauf niedergesetzt hat; der balian-Geist fängt nun alle verborgenen Ecken im Walde zu durchsuchen und durchkriegen an — symbolisch durch die gemalte Schlange dargestellt - und bringt amiroë, nachdem er diesen gefunden, auf die oben beschriebene Weise in den Körper zurück". Tafel VII, fig. 21 geeft een afbeelding van de schommelplank. De onderscheiding van bos- en luchtgeesten moeten we niet te nauw nemen; in het ene geval wijzen vaartuig en vogel naar de luchtgeesten, terwijl de hond aan bosgeesten doet denken; in het 
tweede geval brengt de schommel de balian naar het luchtruim, terwijl de slang een uitgesproken vorm is voor aard- en boomgeesten.

Bovenstaand bericht, dat ik aan Dr. W. H. Rassers te danken heb, wordt aangevuld door een mededeling over het schommelen bij de Malanau-dajaks, waarop Mr. F. D. E. van Ossenbruggen mij opmerkzaam maakte. In het pas verschenen werk van Sir James G. Frazer „Aftermath” (bl. 336, 337), een supplement op zijn grote werk „The golden Bough" haalt de Schrijver een bericht aan van F. B. Mulder en J. Hewitt „Two religious Ceremonies among the Milanos of Sarawak" (Journal of the Straits Branch of the Royal Asiatic Society, no. 57, January 1911, p. 172-177), waarin verteld wordt dat deze Dajaks behalve een schommel ook een boot van acht à negen voet lengte gebruiken, die met touwen aan de zoldering van het huis is opgehangen. Wanneer de sjamaan een poos lang heen en weer geschommeld heeft onder het zingen van litanieën, wordt de patient zelf op de schommel gezet, die door de sjamaan wordt opgegeven. $\mathrm{Na}$ hem maken ook andere personen van de gelegenheid gebruik om te schommelen, teneide hierdoor gezond en sterk te worden. Als de zieke te zwak is om op de schommel te zitten, wordt hij in de boot gelegd, en daarin heen en weer gewiegd. Een ziek kind neemt de sjamaan onder het schommelen op de schoot. Als de sjamaan begint te schommelen, doet hij dit langzaam, maar zijn bewegingen worden hoe langer hoe sterker en vlugger, en zijn stem wordt hoe langer hoe luider, tot hij als waanzinnig wordt. Bij zulk een behandeling krijgt de patient een andere naam, waarmee hij voortaan wordt genoemd.

Aan deze mededelingen omtrent de Dajaks moet ik nog een enkele toevoégen, die te eigenaardig is om haar weg te laten. Dr. Rassers heeft er mij op gewezen. Ook nu geldt het weer het genezen van een kranke; dit gaat gepaard met een plechtigheid, waarvoor de sjamaan (hier bij de Maanjan-dajaks wadian geheten) allerlei dingen gereed heeft te maken. „Gewöhnlich benutzt er ein kleines Boot, etwa ein Fuss lang. Dies hängt er nun in der Türöffnung auf, setzt ein brennendes Wachslicht hinein und schaukelt es hin und her, während er daneben sitzt und Zaubersprüche hersagt. Das erste Insekt, das nun dem Lichte nahe kommt, Fliege, Mücke oder Käfer, wird von dem wadian gegriffen, denn es ist die verlorene Seele. Er tut es in das vorhin erwähnte Töpfchen mit Oel, geht damit zu dem Kranken, schmiert ihm dem Oel auf den Kopf und sucht so die Seele zurückzubringen" (Sundermann, 467). 


\section{Schommelen op Sumatra.}

Op Sumatra richten wij het eerst de blik naar de Karo-bataks. Van het schommelen van dit volk heeft de heer J. H. Neumann mij veel merkwaardigs verteld. De Karo-bataks schommelen graag. Dikwijls maken kinderen schommels van idjoek-touw of rotan onder de woning of de rijstschuur; maar het liefst maakt men hierbij gebruik van de luchtwortels van een waringin. Bij veel dorpen staat zulk een boom aan de ingang van de nederzetting, zodat men niet ver behoeft te gaan om zich te schommelen. Gewoonlijk wordt in het benedeneind van een luchtwortel, niet hoog boven de grond, een stuk hout gebonden, en daarop zit of staat de schommelaar met een been of voet aan elke zijde van de wortel. Maar men knoopt ook wel twee wortels aan elkaar, ongeveer een vadem boven de grond; de onder de knoop afhangende stukken worden vaneen verwijderd en daartussen wordt een stuk hout vastgemaakt, zoodat men erop kan zitten.

Tegenwoordig vermaken zich alleen kinderen met schommelen, maar volgens veler getuigenis zag men vroeger ook vaak volwassenen schommelen, zowel mannen als vrouwen. In de oude tijd moet men dikwijls een schommel hebben onderhouden, die aan de waringinboom bij de ingang van het dorp was opgehangen. Voorbijgangers, die even wilden rusten, konden van de schommel gebruik maken. Ook de bewoners van het dorp schommelden er vaak.

Er bestaat een verhaal om te verklaren, waarom aan de waringin van het dorp een schommel werd gehangen. Er was eens een groot vorst ; zijn dorp lag tegen de zonsopgang (het Oosten) en heette Negeri Poerba. Hoewel zijn rijk groot was, vreesde hij toch andere rijken. Hij vreesde dat anderen hem zouden komen belegeren. Hij was ook een groot tovenaar, maar hij vertrouwde zijn magische kunsten niet geheel. Daarom verzon hij de volgende list, om tegen zijn vijanden op zijn hoede te zijn.

Hij riep zijn onderdanen samen, en beval de Hoofden om mee te brengen: loten van arintoehoeng; anderen moesten brengen salaboelan, en lagere hoofden beringin, terwijl de dorpstovenaars djabidjabi moesten aandragen. Al deze woorden zijn de namen van ficussoorten.

Toen al de volkshoofden bijeen waren, sprak de grote vorst: „De naam van dit feest is ,het planten van magische woorden”, nl. pangoeloebalang, siolang-olang, si rongkang-rangkin, pagar perlindoengan, enz. Plant de arintoehoeng en djabi-djabi bij de dorpsingang stroom- 
afwaarts, en de salaboelan en beringin bij de dorpsingang stroomopwaarts". Hij gaf hun ook toverbrij om samen met de bomen te planten.

Maar de bedoeling van den vorst was om zijn dorp gemakkelijk te kunnen bewaken. Want bij. de dorpspoort liet de vorst zijn voorvechters verblijven om te waken. Om hen nu niet te laten luieren, beval hij ze te gaan schommelen aan de luchtwortels van de geplante bomen. „Maar,” zei hij, , ,gij moogt niet juichen bij de plaats van de pangoeloebalang (de steen die op het dorp past), want dan zou hij boos worden".

Maar de vorst bedoelde, dat ze wél schommelen, maar geen leven maken mochten, anders zouden ze den vijand niet horen naderen.

Dit is het verhaal waarom men vroeger bij de dorpsingang steeds een schommel had. Het is afkomstig uit Serdang.

Tegenwoordig kent men geen vaste tijd waarin geschommeld wordt. Alleen uit de Goenoeng-goenoeng vernam de heer Neuman het volgende: Als de rijsthalmen gezwollen zijn, maar de aar nog niet te voorschijn is gekomen, welk stadium beltek beroe ,vrouwenbuik" geheten wordt, spelen de kinderen met de proppenschieter. Dat doet men om het uitkomen van de aar te bevorderen. Is dit stadium voorbij, dan begint de tijd van het schommelen.

Evenals bij de Toradjas is ook in de dierenverhalen der Karobataks sprake van een schommel. Als Si Pais, de Pelandoek djinaka van dit volk, een kikvors in een strik heen en weer ziet slingeren, krijgt hij lust om te gaan schommelen. Hij maakte de kikvors los uit de strik, en klemde zichzelf in de lus. Maar toen kon hij er niet meer uit. Daarom haalde hij een aap over hem los te maken en zelf te gaan hangen.

Hier volgen enige liedjes die bij het schommelen worden gezongen: ze zijn opgetekend en vertaald door den heer Neumann.

I. Djolē-djolē tjoetjoek, rimanna, doea kali. koedjolē, reh gedang. Belinna, mbelin gia ningkoe, siat nge ibas roemah, gedang gia ningkoe labo tondel langit. Kerbak-kerbas, nangka tasak, baban koe tiga Nderket.
Schommelen, schommelen, liefje, twee keer schommel ik je, wordt je langer en dikker.

Al zeg ik ,groot”, je past nog in huis,

Al zeg ik ,lang”, je stoot niet tegen de hemel.

Kerbak-kerbas, de nangka-vrucht is rijp om gebracht te worden naar de markt Nderket (als 
de nangka-vrucht rijp is, is ze zacht en moet ze dus zacht neergelegd worden; zo ook het kleine kind).

II. Djolē-djolē! Djolē-djolē! reh gedang-belinna; doea kali koedjolē, belinna asa roemah; teloe kali koedjolē, gadangna asa dalin. Gerbas, gerboem! nangka tasak bahan koe tiga Nderket.
Schommelen, schommelen! (bis) wordt groter en dikker; tweemaal schommel ik je, zo groot (hoog) als een huis; driemaal schommel ik je, zo lang als de weg.

Gerbas, gerboem! de nangka is rijp om naar de markt Nderket gebracht te worden.

III. Het volgende liedje wordt gezongen terwijl men kinderen bij de armen pakt en zo laat schommelen. Bij het laatste woord plaatst men het kind op de schoot van de moeder of legt het op de grond.

Djolē-djolē, gedangna asa dalin, Schommelen, schommelen, zo lang als de weg, belinna asa deleng. zo groot als de berg.

Mbelin gia ningkoe, siat kentja Al zeg ik ,groot” je kunt maar precies door de pintoën.

Gedang gia ningkoe, ola tondel langit.

Kerbak-kerboes, nangka tasak, Kerbak, kerboes, enz. bahan koe tiga. Nggoh!

De berichtgever van den heer Neumann merkte op, dat er een betekenis achter deze woorden schuilt. „Gedang 1a tondel langit, belinna siat nge roemah" zou gezegd worden uit vrees, dat het kind zal sterven. Want men meent, dat als iemand sterft en verbrand wordt, ,,zijn rook de hemel raakt”. En ook: ,als iemand sterft, moet hij 't huis uit". Om dit te verhoeden, zingt men deze woorden.

Een merkwaardige manier van schommelen houden de Koeboes in de Res. Palembang erop na. Dit gebeurt bij het sluiten van een huwelijk. Wanneer nam. bruid en (of) bruidegom voor de eerste maal in 't huwelijk treden, wordt een soort weegschaal opgesteld, waaraan aan beide einden een schommel wordt gehangen. Bruid en bruidegom gaan elk op een schommel zitten; ze worden niet alleen geschommeld, maar ook gewogen. Blijkt de een zwaarder te zijn dan de ander, dan wordt op de schaal van de lichtste zoveel lemang (in bamboe gekookte 
rijst) en andere spijzen gelegd, dat de hefboom in evenwicht is. Onder het wiegen van het bruidspaar worden allerlei zegenwensen voor de toekomst uitgesproken. Huwt slechts één van de partijen voor de eerste maal, dan wordt deze alleen op de ene schommel gezet, terwijl op de andere schaal alleen de genoemde etenswaren worden gelegd, zoveel als het gewicht van de gewogen persoon is.

Deze plechtigheid heeft op een malim- of sjamanen-feest plaats, dat de naam draagt van bermalim timbang doendangan, zoveel als ,het sjamanenfeest van het wiegeliedjes zingende wegen" (v. Dongen 1, 284-285). Verteld moet worden, dat op dit feest, evenals bij andere dergelijke gelegenheden, een bringin toedjoeh pangkat ,waringin met zeven lagen of takken" aanwezig moet zijn. Dit voorwerp is ,een bamboe van 5 tot 7 voet lang, waaraan en omheen op gelijke afstanden zeven naar boven toe kleiner wordende vierkante ramen van bamboe zijn bevestigd, die van onderen ongeveer $3 \mathrm{dm}$ lang en breed, en van boven ongeveer $2 \mathrm{dm}$ lang en breed zijn. Deze ramen zijn versierd met planten, waaraan veel stekels en doornen zitten, zooals rotanbladeren. Aan de uiteinden van zulke bladeren zijn běrtih(gepofte rijst-)korrels vastgekleefd, terwijl verder daartusschen allerlei bloemen zijn vastgehecht" (v. Dongen 1, 277). Dit is dus een imitatie-waringinboom, op de betekenis waarvan ik in de samenvatting aan het eind van dit opstel terugkom.

Omtrent de bedoeling van deze plechtigheid vertelt van Dongen, dat de malim (doekoen) bij deze gelegenheid de betaling ontvangt voor de hulp en de diensten, die hij aan bruid en (of) bruigom, toen ze nog kleine kinderen waren, heeft bewezen, in tijden van ziekte of andere ongunstige omstandigheden. Dat met dit schommelen niet altijd gewacht wordt tot het kind volwassen is en trouwen gaat, blijkt uit een mededeeling van Prof. Schebesta (aangehaald bij v. Dongen 2,571 ), die van een malim-feest vertelt tot genezing van een ziek kind; na afloop van welke plechtigheid een weegschaal werd opgesteld met een schommel aan elke kant; op de ene schommel namen de moeder en haar zieke kind plaats, op de andere werd een mand gezet, waarin de kop van de geslachte geit met rijst en andere eetwaren waren gedaan.

Beide schommelplechtigheden, bij huwelijk en tot genezing van een ziek kind, komen op hetzelfde neer: het heil, de gezondheid van het kind te bevorderen. Het schommelen bij de huwelijksvoltrekking is te beschouwen als het uitgesteld schommelen van het kleine kind: bij de intrede van een belangrijke levensperiode, waarin het kind, groot 
geworden, zelf kinderen zal gaan voortbrengen, moet het verzuim of het uitstel worden ingehaald. Van Hasselt (124) zag bij de Koeboes een schommel van rotan, waarop een vrouw zat met een kind aan de borst, die zichzelf wiegde. Dit is dus een aanvulling van hetgeen Prof. Schebesta bericht.

Ook voor de Rawa-streek vermeldt Van Hasselt de schommel : „De Maleische schommel.... is van een bamboestaak vervaardigd die aan een boomtak hangt. Maar het schijnt dat de kinderen niet veel genoegen vinden in deze beweging, te oordeelen naar de weinige malen, dat wij zulke schommels bij de huizen in een boom zagen hangen" (van Hasselt, 124). De plaat laat een bamboestengel zien die aan het ene eind gespleten is; daarin wordt een boomtak geklemd, terwijl boven de tak een houten pen door de bamboe helften wordt gedreven, waaraan de staak dus komt te schommelen. Aan het benedeneind is de bamboe doorboord, en door het gat is een stok gestoken, waarop men kan staan of zitten. Bizonderheden van het schommelen worden niet vermeld.

Voor het laatste voorbeeld, dat we op Sumatra van schommelen vinden, moeten we naar Bengkalis. Hier heeft het schommelen plaats bij gelegenheid van de troeboek-visserij, opdat deze veel profijt zal opleveren (Gramberg, 310-316). In 't kort komt de plechtigheid op

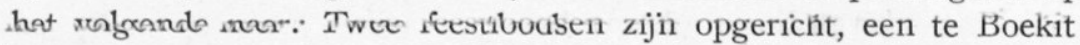
batoe, en een aan de mond van de rivier Bengkalis; ze zijn versierd met loof en katoen, waarvan het grootste deel geel gekleurd is. De hoofdpersoon is de Djindjang Radja, een vrouw van burgerlijke afkomst; deze waardigheid is erfelijk in de familie. De toenmalige leidster was een oude vrouw, Embong Edah. Vier oude dorpshoofden, die de titel voeren van bathin, treden op als rijksgroten van de Djindjang Radja en vergezellen haar naar de feestloods. Ze neemt plaats op een soort divan bekleed met gele zijde; haar hoofd is bedekt met een geel zijden doek; in de hand houdt zij een geel zijden doek waaraan gouden franjes, benevens een waaier met gouden rand. De vier bathins voeren een dans uit om haar heen, en begeven zich dan naar de vier hoeken van de loods, waar niemand anders een voet mag zetten. De Djindjang Radja wordt dan in trance gebracht door het branden van wierook en andere dingen, en in die toestand geeft ze haar aanwijzingen voor het feest.

Het grote ogenblik is gekomen, als de Djindjang Radja te kennen geeft, dat moet worden opgebroken naar de riviermond om Djangi, de godheid van de troeboek, aan te roepen, Is het sein daartoe gege- 
ven, dan zakt men in prauwen de rivier af naar de feestloóds, die aan de monding gereed staat. Hier zal het eindorakel gehouden worden.

In de loods aangekomen gaat de Djindjang Radja weer op een gele divan zitten. In de loods is o.m. een met geel doek beklede schommel, dondang, behangen met gouden klokjes. De Djindjang Radja wordt weer bewierookt, met reukolie gezalfd, en met rijstkorrels bestrooid, totdat de geest in haar vaart. „Ook de bathins schijnen nu door die geestverrukking aangestoken te worden en stellen zich aan als bezetenen. Ze tieren, rollen zich over de grond, en slaan met armen en beenen".

Als de Djindjang Radja tot kalmte is gebracht, wordt ze ,door haar vier staatsdames naar den schommel geleid, waarop zij onder het klingelen der gouden klokjes plaats neemt. $\mathrm{Nu}$ worden een voor een de zestien geesten opgeroepen, die met de zaak der visscherij te maken hebben.... Zacht schommelend spreekt nu de Djindjang Radja tegen die onzichtbare geesten, en daar niemand die taal verstaat, vertaalt de bidoe (haar helpster) hetgeen de geesten antwoorden". Elk der geesten geeft een verschillende reden op, waarom de vissent wegblijven, en ze openbaren ook het middel, waardoor de belemmering wordt opgeheven. Eindelijk geeft god Djangi te kennen, dat hij voldaan is, en dan gaat men elkaar in de prauwen bekogelen met pakjes rijst (ketoepat) en gebak. Daarmee is het feest afgelopen, en de Djindjang Radja keert als een gewone vrouw naar haar woning terug.

\section{Schommelen op Java.}

Op Java wordt overal door kinderen geschommeld. Allerlei soorten van schommels worden gemaakt, van een enkel touw waaraan men zich vastklemt en heen en weer slingert, tot een keurig ingerichte schommel, waarop men zich op z'n gemak kan wiegen. Daar mijn onderzoek naar bizonderheden zich hoofdzakelijk tot het Malangse op Oost-Java heeft bepaald, vanwaar ik door tussenkomst van den heer S. S. de Vries uit verschillende dessa's inlichtingen heb ontvangen, kan ik alleen vandaar bizonderheden meedelen.

Van deze streek horen we dan, dat bruid en bruigom zich wel eens samen op een schommel zetten en geschommeld worden; waarom dit gedaan wordt, kon men niet zeggen. De tijd waarin men veel schommels ziet, in en bij huis, bij de sawah, is die waarin de rijst aan het uitkomen is. Men zegt dan te schommelen, opdat de aren lang en zwaar zullen zijn, want Sang dewi Seri, de rijstgodin, is verzot op 
schommeleh. In de oude tijd schommelden ook volwassenen, als ze van adel waren.

Wanneer men voor de eerste maal van de nieuwe rijst eet, mag men deze niet nuttigen terwijl ze nog warm is; men moet de schaal of pot met rijst dampend op de schommel plaatsen om een zegen van Sang dewi Seri te ontvangen. Eerst als de rijst op de schommel is afgekoeld, mag men haar eten. Er bestaat echter geen tijd waarin schommelen verboden is, maar terwijl men de sawahs bewerkt, is er geen gelegenheid voor dit vermaak.

Men zingt bij het schommelen. Soms is het liedje van geen betekenis :

Joen ijoenanta, tiba ra larata, bendjoek sakalapa, d.i. Schommelen, schommelen, als je eraf valt doet het je geen pijn, maar je krijgt een bult (zwelling), zo groot als een kokosnoot.

Willen verliefde jongelui hun genegenheid voor elkaar openbaren, dan zingen ze: Joen bandoel, Djekoetek noenggang djaran, djarane mlajoe ngetan, ditoetoeti bok perawan, sangoene 'mbako idjo, lawaslawas dadi bodjo. D.i. Schommelen-schommelen. Djekoetek (gefingeerde naam voor degeen die op de schommel zit) rijdt paard, het paard holt naar het Oosten, wordt achterhaald door mevrouw maagd, wier reisvoorraad groene tabak is, op de lange duur wordt zij zijn vrouw.

\section{Schommelen op Bali.}

Wat het schommelen op Bali betreft hebben we uitvoerige berichten van Dr. V. E. Korn in zijn beschrijving van ,de dorpsrepubliek Tnganan Pagringsingan”. Hij vertelt dat onder de aan plechtigheden rijke maanden van het jaar de vijfde uit godsdienstig oogpunt de voornaamste is, ,de dan gevierde atji sasih kalima of oesaba sambah (sambahfeesten-serie) is voor de Tngananners van groote beteekenis". „Welke die beteekenis is valt niet met zekerheid vast te stellen. Wel is duidelijk dat men moet denken aan een groot allerzielenfeest". Men heeft de gedachte, dat de meisjes door al de verrichte plechtigheden gereinigd worden, tot de staat gekomen zijn van satija, d.i. vrouwen die haar geliefde in de dood volgen. Haar optreden heet dan ook manoeroen béla. Ze moeten geheel in 't wit gekleed zijn en haar haren los laten hangen. Het doel van dit feest is om alle onreinheid van de streek (lteh djagat) op te heffen (Korn 200). Op de negende dag van de tweede helft van de vijfde maand kleden de maagden zich op haar 
fraaist; ze worden dan vergeleken met bidadari, d.i. hemelnimfen. De bedoeling is dus dezelfde als die welke besloten ligt in de boea'- en meraoek-feesten van de Zuid-toradjas en de To Seko. Het voornaamste middel nu om de meisjes tot deze staat van reinheid, we zouden willen zeggen ,hemelsheid”, te brengen is, dat zij herhaaldelijk door de jongelingen (troena) worden geschommeld.

„In deze maand worden de schommels, anjoenan of pamidang, gebezigd, vertelt Korn (188). Deze groote Turksche schommels vindt men in Kloengkoeng, Karangasem, Noesa Penida en elders als kermisvermaak in verschillende dorpen. In Tnganan vormen ze echter een stuk van de adat en den godsdienst. Van deze anjoenan, die niet gelijk elders zitstoeltjes hebben, worden er vijf opgericht, een voor elke patmon (wijk), en elk bestemd voor acht personen. Dit zijn de anjoenan bandoeng. De beide andere verrijzen voor de balè agoeng (het forum), zijn ingericht voor vier personen en heeten anjoenan djantra. De noordelijke van dit tweetal heet anjoenan sahat (pa sahat is de aanspreektitel door de troena - jongelingen — en dha - maagden - gebezigd tegenover de krama desa — gehuwde burgers). De zuidelijkste heet anjoenan di pakoewon". Jongens en meisjes worden gescheiden, doordat de jongelingen in deze maand gedurende een aantal dagen in hun verzamelhuis of patmon slapen.

In de vroege morgen van de negende dag van de feestmaand zijn de jonge mannen begonnen de pamidang bandoeng op te stellen. Over dit werk wordt drie dagen gedaan, gedurende welke tijd de jongelui door hun palak, d.i. vroegere leden van de jongelingsbond, onthaald worden. Op de 10e en 11e dag worden de anjoenan sahat en de anjoenan di pakoewon opgericht. Op de 12e dag brengen de jonge mannen in de door hen opgerichte schommels de houten ramen aan, waarin de meisjes gaan zitten, wanneer ze rondgedraaid worden (Korn 190).

Wanneer nu de schommels gereed zijn, worden ze gewijd door een offer. Dit offer is de banten komaligi, dat samengesteld is uit bestanddelen van alle gewassen, geschikt in een vierkant houten bakje, in het midden waarvan een lampje staat. Eerst wordt dit offer naar de balè agoeng (forum) gebracht, en vandaar door vijf personen naar de schommels, vijf, voor elk één, dan in de schommel gezet, die daarop door den laagstgezeten troena of jongeling rondgedraaid wordt, driemaal heen en driemaal terug. Is de lamp weer beneden gekomen, dan zet zich de jonge man voor het offer op de mat op de grond, waarna hij met een stukje katoen gedrenkt in de olie van het lampje, de ver- 
schillende bestanddelen van het offer bestrijkt, en tenslotte de lamp uitdrukt. Volgens mededeling van den Idjeng is de lamp een voorstelling van de ziel, het driemaal ronddraaien dient om de ziel de marga tiga, de drie wegen die ze bij het vrijkomen van het stoffelijk lichaam na overlijden van den mens kan kiezen, te leren kennen (Korn, 191).

Wanneer de komaligi teruggebracht is. begeven de meisjes zich met haar leidsters naar de verzamelloods der jongelingen om zich door hen te laten schommelen. Voor elke patmon of afdeling worden ze vijfmaal rondgedraaid. „Dit schommelen geschiedt aldus, vertelt Korn. In elk der beide palen waartusschen de as van den molen is bevestigd, klimt een troena, die met den voet telkens een flinken trap geeft op elke spaak waaraan een schommel hangt”. Dit is dus de eerste maal, dat de meisjes geschommeld zijn, en van nu afaan beginnen de troena met in hun vergaderloods (patmon) te slapen.

Een belangrijk punt in het feest is dat voor elke vergaderloods der jongelingen vruchtbomen worden geplant, waaronder een pinangboom, een arèn en een kokos. In de middag van dezelfde dag gaan ook alle desavrouwen, fraai uitgedost, in optocht bezoeken afleggen in de drie patmon, en laten zich door de jongelingen schommelen.

Op de $2 \mathrm{e}$ dag van de tweede helft der maand kleden de jongelingen zich bizonder fraai aan; ze dragen een kris met het zwart, wit en rood gekleurde koord (bnang tridatoe), en opgerold pisangblad (soebeng) in en bloemen achter het oor. De meisjes komen dan weer naar de patmon, en vragen om geschommeld te worden. In iedere patmon houdt dan, alvorens aan dit verzoek voldaan wordt, een troena een toespraak, waarbij hij een spaak van de schommel vasthoudt. Hij brengt de regelen van het ganse feest, de oesaba sembah, in herinnering.

Het feest is een aaneenschakeling van allerlei plechtigheden: optochten, dansen, wassingen, offeranden, maaltijden. Al deze handelingen worden afgewisseld door het schommelen van de meisjes, en dit gaat zo voort tot het eind van het feest, d.i. op de eerste dag van de zesde maand.

Een paar handelingen op het feest dienen nog vermeld te worden, teneinde de betekenis ervan te kunnen bepalen. In de tweede helft van de maand nam. heeft herhaaldelijk stelen van vlees, afkomstig van de geslachte dieren, plaats. De troena stelen het uit de balé agoeng, en dan wordt het weer teruggestolen door de pangloedoehan, d.z. zij die nog niet lang geleden gehuwd zijn. Telkens worden de 
dieven vervolgd, en als ze gepakt worden, naar de verzamelplaats der jongelingen of naar de balé agoeng gebracht.

„Van de gevangenen (bebandan) worden de twee jongste troena in de balé agoeng en de twee jongste pangloedoehan in de tmoe klod gekneveld met vleeschbanden om armen en hals; zij krijgen een stroowisch om het voorhoofd, een kleedje van pisangbladeren aan, een karbouwenstaart achter in den gordel, een stuk karbouwenhuid als baard om de kin en een karbouwenpenis met twee varkensblazen als afzichtelijk groot scrotum tusschen de beenen. Als kris dragen ze op stokjes geregen stukjes vleesch. Zóó toegetakeld worden ze door het dorp gevoerd". Dan worden ze naar het vergaderhuis (soebak) der meisjes gebracht, waar ze om djadjan bedelen. Ze worden rijkelijk op koekjes onthaald, keren terug naar de patmon en de balé agoeng, en gaan dan naar huis; de vleeskledij mogen ze houden (Korn, 199).

Het tweede dat vermeld moet worden is de prang pandan, het vechten met pandan-bladeren, het gboeg of maèndé. Dit heeft plaats op de 7e dag van de tweede helft der feestmaand. In de morgen worden verscheiden tempels gereinigd, waar men bidt, en dan heeft in de middag het gevecht plaats.

„Voor dit gboeg zijn de mannen en jongelieden uit Ngis verplicht over te komen. $\mathrm{Zij}$ worden uitgedaagd tot een tweegevecht, waarbij een jonge man van Tnganan, gewapend met een schild (èndé of presian) en een bundel gedoornde pandanbladeren, tandakkend en onder hoongebrul te kennen geeft, dat hij bereid is den strijd aan te binden met een geschikt tegenstander. Dan treedt, terwijl de slonding een opwindende muziek laat horen, een jonge man uit Ngis te voorschijn, die zich ook voorziet van een schild en pandanbladeren, en door het volbrengen van eenige bevallige danspassen te kennen geeft, dat hij de uitdaging aanneemt. Wordt hij een niet te zwaar tegenstander geoordeeld, dan gaat het tweegevecht door en probeeren beide jonge kerels elkaar de huid open te halen met de gedoornde bladeren (nganggèt anggèt), waarbij de aanvallen met het schild afgeweerd dienen te worden. Acht de uitdager den tegenstander een te zware partij, dan kan hij zich zonder schaamte terugtrekken en neemt een dessagenoot van zwaarder gewicht zijn schild en wapen over: Wie den eersten haal toebrengt heeft den strijd gewonnen en keert met triomfantelijk gezicht en sierlijk dansend den overwonnen strijder den rug toe..... Afgezien van de bloedende schrammen, waaruit men onverwijld de dorentjes gaat peuteren en die met een gele pastei 
worden bestreken, maakt deze strijd een vroolijken indruk en het publiek leeft dan ook juichend mee” (Korn, 201).

\section{Schommelen in 't oostelijk deel van de Archipel.}

Ofschoon het in de literatuur niet opzettelijk vermeld wordt, mogen we toch aannemen, dat schommelen althans als vermaak van kinderen op de kleine Soenda-eilanden en in de Molukken bekend is. De meeste woordenlijsten van de daar gesproken talen geven woorden op voor „schommel” en ,schommelen”. Door eigen onderzoek kwam ik te weten, dat een schommel van touw of rotan op Rote leleoek heet, en wanneer men hiervoor een afhangende boomtak bezigt, aan welks uiteinde men zich vastklampt om zich zó heen en weer te schommelen, heet dit boboik. Schommelen wordt alleen door kinderen gedaan. Op een schommel zetten zich soms twee of drie kinderen tegelijk. De heer Ngefak deelde mij mede, dat men onder het schommelen zingt: Lèlèoe doko, temoe te mai; lèlèoe doko, boso pesi, boso monoe „Sprinkhaan-schommel (d.i. schommel die het vermogen heeft in de hoogte te springen als een sprinkhaan), heen en weer ; sprinkhaan-schommel, glijd er niet af, val niet op de grond". Ook bij het schommelen aan een boomtak zingt men: Boboi beba lati dèlè lama koka. Boboi beba tona oefa tasi pena, wat vrij vertaald betekent: Schommelen als zittende op een bladschede van een palm, en als een prauw die op het schuim der golven zonder ophouden op en neer gaat.

Van een schommel wordt melding gemaakt in de folklore van Rote. Men vertelt namelijk, dat ziekten en kwalen op een schommel liggen, die in de hemel heen en weer bewogen wordt; nu en dan valt een ziekte van de schommel af; de bewoners van de streek waar de ziekte neerkomt, worden dan krank.

Omtrent de Rokka's van Midden-Timor hebben wij de volgende mededeling: „Bij de geboorte van het eerste kind geeft men na twee dagen het géoe-noeké-feest, waarbij een of meer varkens worden geslacht. Géoe noeké wil zeggen de deurpost, noeké, wiegen, dit is een handeling die de moeder moet verrichten, alvorens na haar bevalling het huis te mogen verlaten, en deze gaat soms met een feest gepaard" (v. Staveren, 144). Nadere toelichting hoe dit toegaat, wordt niet gegeven.

Zelfs bij de Papoeas op Nieuw-Guinea vinden wij een voorbeeld van ritueel schommelen. Van de Kai-papoeas in het voormalig Duits 
Nieuw-Guinea vertelt Keysser: „Von Bedeutung für ein gedeihliches Wachstum der Feldfrüchte sind nach Meinung der Eingebornen verschiedene Spiele, die deshalb nur in den Zeit nach der Feldbestellung gespielt werden dürfen. So soll das Schaukeln an einem langen spanischen Rohr, welches man an einem Baumast befestigt, von guten Einfluss auf die frisch gepflanzten Jams sein. Geschaukelt wird deshalb von alt und jung, von Mann und Weib. Keiner, der ein Interesse an dem Gedeihen seiner Saat im Feld hat, lässt die Schaukel unbenutzt. Beim Hin- und Herschwingen singt man Schatkellieder. Dieselben enthalten vielfach nur die Namen der ausgepflanzten Jams und den in verschiedenen Abarten wiederholten, fröhlichen Enteruf : „Ich habe eine schöne Frucht gefunden!' Beim Abspringen von der Schatukel stösst man den Ruf aus : „Kukulili!” Durch Rufen ihres Namens will man die Keime der Jams aus dem Erdboden herausziehen" (Neuhauss III, 125).

\section{Schommelen in Annam.}

Tenslotte moeten wij nog even buiten de Indische Archipel gaan, en wel naar Annam. Ook hier treffen wij het schommelen aan, wel is waar geheel als spel, maar uit de trekken, die eraan verbonden zijn, blijkt duidelijk, dat het een dieperen zin heeft dan alleen als spel. Nguyen van Huyen beschrijft nam. enkele spelen, waardoor de jongelui van beide geslachten nader met elkaar in aanraking komen. Deze spelen worden gehouden bij gelegenheid van feesten, die in de lente en in de herfst plaats hebben. Het toneel van deze spelen is het grote dorpsplein. Ieder mag er bij tegenwoordig zijn. Bij alle spelen komen een man en een vrouw te pas, die tegenover elkaar staan; meestal zijn ze ongehuwd.

Onder deze spelen nu wordt ook het schommelen genoemd, dat in de landstaal „Du dôi” heet. De Schrijver geeft er de volgende beschrijving van: „Le „Du dôi” consiste en une balançoire montée sur quatre piquets de bambou réunis en pyramide. Au sommet de la pyramide est attachée une barre portant des primes consistant en souliers, serviettes, sapèques, eventails, soie, etc. Un couple, un homme et une femme, est demandé par le gardien du jeu; ce gardien est nommé par le domité des fêtes. Un homme s'avance dans l'enceinte de la balançoire. On crie: une femme! une femme! Parfois le jeune homme fait un petit discours ou récite quelques vers demandant une compagne pour aller se promener comme des immortels. 
Après quelques hésitations, une femme s'avance. On a ainsi un couple. Ils se balancent debout sur le plateau, face à face, tout en chantant ensemble un couplet connu, ou bien en s'interrogeant, l'un l'autre, comme dans les fêtes des chants alternés. Il faut que la balançoire monte, monte toujours, jusqu'à ce que la femme ou l'homme puisse atteindre l'un des objects. Chacun d'eux ne peut prendre qu'un seul object. Si le couple reste trop longtemps sur l'escarpolette sans pouvoir arracher un object, il est expulsé par le gardien. Mais s'il chante bien, on l'autorise à y rester plus longtemps. Dans le cas où il est expulsé, il pourra recommencer après avoir laissé passer quelques autres couples. Le jeu continue jusqu'à ce qu'il ne reste plus aucun object sur la barre. Il y a des endroits où l'on ne donne des primes qu'à ceux qui chantent bien en se balançant sur l'escarpolette. Il y a où l'on ne donne aucune prime. Les autorités ne font que dresser plusieurs balançoires sur plusieurs places publiques. Sans enjeu, les couples chantent aussi longtemps, gaiement" (Nguyen van Huyen, p. 208, 209).

\section{Schommelen in de mythe.}

Schommelen komt in een mythe voor, die over heel de Archipel bekend is. Het is het verhaal van de schoone prinses die door haar jaloerse zusters op zulk een wijze geschommeld wordt, dat zij in zee valt, en daarin verdwijnt. Voor Midden-Celebes tekende ik het op onder de To Rampi' en de To Tobakoe. Voor Java kreeg ik de lezing zoals die in het Malangse bestaat. Loeb (99-101) geeft het verhaal op Mentawai, en Schwartz (67-69) voor de Minahasa. Ik geef de vijf lezingen hier in 't kort weer om de verschillen erin te doen uitkomen.

In Rampi' luidt het verhaal aldus: In de oude tijd was er een meisje dat zeer geliefd werd door haar ouders. Dezen stonden haar niet toe buitenshuis te komen. Dit meisje werd genoemd: ana' nilĕlea „het kind dat goed wordt verzorgd". Deze lieden woonden te Lowa. Op een goede dag kwam het meisje op de voorgalerij van het huis en ging daar schommelen. Toen kwam daar een slechte vrouw, die buiten het dorp woonde, en de naam droeg van Tohaněneka. Deze vrouw gaf de schommel zo'n harde zet, dat het meisje weggeslingerd werd naar Tokoroniho, een plek in de Leboni-rivier, waar deze een grote bocht maakt en een draaikolk vormt, stroomaf van het dorp Bone. Het meisje ging dadelijk in het diepe water onder. Eerst de 
volgende morgen vonden de mensen, die haar waren gaan zoeken, haar. Ze bevond zich toen niet meer in 't water, maar ze zat op de kant; ze maakte garen van boomschors en pruimde bladeren van de poromama (een plant waarvan de onwelriekende bladeren gepruimd worden, dadelijk na het uitslaan der tanden bij de meisjes). Ze had zoveel boomschors en poromama-bladeren bijeen, dat het een bergje geworden was, dat tot op de huidige dag de naam draagt van Biri poromama „poromama-berg”. Het meisje werd naar Lowa teruggebracht, en daar maakte men een feest voor haar terugkeer.

In Towoeloe, een dorp in Tobakoe van de Koro-groep der Westtoradjas hoorde ik het volgende: Een ouderloos echtpaar verlangt naar een kind, ,,al hadde het slechts de gedaante van een varken”. Ze krijgen er een, dat slechts de kop van een varken is, en daarom Woo Wawoe „varkenskop” genoemd wordt. Deze Woo Wawoe huwt met de zevende dochter van den vorst. $\mathrm{Zijn}$ vrouw heeft daarover heel wat te horen van haar zes zusters, die het een schande vinden een varkenskop tot zwager te hebben. Als de zwager later in een schonen prins veranderd is, trachten zijn schoonzusters hem te verleiden, maar hij wil alleen iets van zijn vrouw weten. - Eens zei Woo Wawoe tot zijn vrouw: „Ik ga voor tweemaal zeven dagen op reis, zorg ervoor dat je zusters je geen kwaad doen. Hier heb je een pinangnoot en een ei, die zullen je beschermen". Toen hij was heengegaan, liet zijn vrouw zich overhalen om met haar zusters te gaan schommelen. De schommel waarop ze plaats nam, was van rotan, maar deze was half doorgekapt. Toen ze erop gezeten was, gaven de zusters de schommel een flinke zet, zodat de rotan brak en de vrouw in zee viel, en tot op de bodem neerzonk. Maar op hetzelfde ogenblik schoot de pinangnoot op tot een hoge boom, en het ei brak, en er kwam een haan uit, die op de top van de pinangboom naar boven gevoerd werd. $\mathrm{Na}$ veertien dagen keerde Woo Wawoe in zijn schip naar huis terug. De haan kraaide hem uit de verte toe: „Kukeleku! Je vrouw ligt dood op de bodem van de zee". Toen haastte Woo Wawoe zich naar het strand. De schoonzusters stelden weer alles in 't werk om hem te verleiden, maar hij wilde niets van haar weten. Hij nam zeven flessen olie, en ging op de pinangboom zitten. Deze schrompelde ineen tot op de bodem van de zee. Daar vond Woo Wawoe zijn vrouw; hij makte haar met de olie weer levend, en ze was weer even mooi als tevoren. $\mathrm{Nu}$ keerde hij met haar naar huis terug en joeg zijn schoonzusters de deur uit.

Van Oost-Java werd mij het verhaal meegedeeld door den heer Deel 97 
Arban Mariatin, toenmaals onderwijzer te Melaten: Er waren drie prinsessen van Mesir (Egypte), die gewend waren aan de oever van de zee te schommelen. Ze heetten Gading, Kenanga en Melati, alle namen van bloemen. Gading en Kenanga hielden niet van Melati, omdat zij de fijnste en de mooiste van haar drieën was; daarbij de zachtmoedigste en bescheidenste, en de eerbiedigste tegenover oude mensen. Daarom kwamen veel prinsen naar haar hand dingen. Op zekere dag haalden de zusters Melati over om mee te gaan schommelen aan de oever van de zee. Ze schommelden beurt om beurt. Toen Melati geschommeld werd, zongen de zusters : „Schommelen, schommelen, Bok Melati wordt tot midden in de zee geschommeld". Tegelijkertijd gaven ze de schommel een hevige zet, zodat Melati eraf schoot, in zee viel, en daarin verdween. Toen zag men een duif uit de zee opwaarts vliegen: dewi Melati was een vogel geworden. Deze volgde altijd Gading en Kenanga. En wanneer een prins om de hand van een harer kwam vragen, zong de vogel: „Doedoe ikoe, dekoekoe doedoe ikoe, karo demen padoe, dekoekoe-koe-koe”, d.i. „,háár niet, dekoekoe (koekeroe), háár niet, want ze houdt van ruzie" (vert. van Prof. Berg).

Op Mentawai bevalt een vrouw van een kat. De moeder vraagt voor het dier een van de drie zusters ten huwelijk; alleen de jongste verklaart zich hiertoe bereid. Als de kat zich in een schonen jongeling veranderd heeft, zijn de zusters jaloers. Toen Kat op een morgen uit vissen ging, waarschuwde hij zijn vrouw om niet met haar zusters te gaan schommelen. Ze deed het toch, en toen ze aan het schommelen was, brak het touw en viel ze in het water. Ze kwam op een verlaten eiland terecht, waar ze door haar toverkracht haar huis en haar huisraad bij zich liet komen, en ze ging koken. Kat was in zee aan 't vissen. Hij zag de rook van het haardvuur en hij begreep dadelijk, dat dit zijn vrouw was. Hij ging erheen en bracht zijn vrouw naar huis terug. Hij verborg haar onder een zonnehoed (turok) toen hij aan land kwam, zodat de zusters haar niet konden zien. Thuisgekomen verbood Kat de zusters ooit meer in zijn huis te komen (Loeb, 99101).

Het verhaal in de Minahassa luidt aldus (Schwartz, 67-69): Een ouderpaar krijgt een zoon, die niet meer dan een stomp is, Si Koesei, een mensengedaante zonder armen en benen. Deze laat zich naar den koning brengen, en vraagt hem een zijner negen dochters ten huwelijk. De ouderen weigeren allen den Stomp tot man te nemen; alleen de jongste stemt toe in het huwelijk. Wanneer dan later het "Stompje” 
zich in een schonen jongeling ontpopt en het jonge paar zich in weelde baadt, zijn de zusters jaloers. Als de Stomp dan eens op reis is gegaan, ,maakten hare acht zusters met elkaar een geheime afspraak tegen zijn vrouw, dat zij door haar in 't ongeluk zou gestort worden, omdat zij haar benijdden, dewijl zij door den Stomp was gehuwd. Daarom noodigden hare oudere zusters de Vrouw van Stomp uit en zij gingen schommelen op een schommel aan den oever der zee. Naar hare afspraak zouden zij de jongste, als deze aan het schommelen was, met kracht in zee duwen, en zoo zou zij verdrinken. Toen zij dan gingen schommelen, ging de oudste het eerst en de anderen volgden haar op, tot aan de jongste toe. Toen de Jongste schommelde, duwden ze haar met kracht naar de zee, zoodat zij om genade smeekte, maar ze duwden haar des te krachtiger. Aldus werd de vrouw van den Stomp naar een eiland toe geslingerd, dat niet door menschen bewoond was". Het vervolg is dan weer, dat haar man haar vindt, naar huis brengt, en de zusters voor haar wandaad straft.

$\mathrm{Bij}$ de Oost-toradjas heb ik dit verhaal niet gevonden. We hebben hier klaarblijkelijk met een maanmythe te doen. De smalle sikkel van de bijna verdwenen maan is de schommel, waarmee de prinses in zee wordt geslingerd. In Voor-Indië komt de schommel nog voor in verband met de maan. Prof. J. Ph. Vogel te Leiden maakte mij opmerkzaam op een plaats in Annual Report of the archaeological Survey of India for the year 1903 - 4, waar Dr. Theodoor Bloch op bl. 125 zegt: „The great festival of the vernal fullmoon on Phālguna, the modern Holi, is still called dol-jātrā or ,,swing-festival” in Bengal”.

\section{Sa ménvatting.}

$\mathrm{Nu}$ we alle beschikbare gegevens over schommelen in de Indische Archipel bijeengebracht hebben, kunnen we nagaan wat de bedoeling daarvan moet geweest zijn. Daartoe moeten we eerst het karakter bepalen van die feesten, waar het schommelen een belangrijk deel van de plechtigheden uitmaakt. Deze feesten zijn het merahoeng en ma'boea' van Pada-Seko en het oesaba sambah $^{1}$ ) van Bali. Het verloop van deze feesten bewijst, dat we hier te doen hebben met ,stamfeesten". Van het stamfeest op Midden-Celebes heb ik, naar ik meen, aangetoond, dat de bedoeling daarvan is de hemel (als luchtruim, uit-

1) Sambah, Jav. sembah, vinden wij bij de Oost-toradjas terug in mesomba, monjomba, waarmee speciaal bedoeld wordt het aanroepen van den Hemelheer bij gelegenheid van het stamfeest (Kruyt 2, 556). 
spansel) met zijn licht, leven en kracht op aarde te brengen, of wil men: de aarde met haar mensen, huisdieren en gewassen in de hemel te brengen; in elk geval een innig verband te bewerkstelligen tussen het middenrijk (de aarde) en het hemelrijk.

We zien in Pada-Seko en op Bali, dat van de meisjes en vrouwen veel werk wordt gemaakt. Van haar toch hangt het af, of de stam in aantal zal toenemen. Zij vooral zijn het die in nauwe aanraking gebracht moeten worden met het leven van de hemel. In de beschrijving van het stamfeest op Midden-Celebes, heb ik aangetoond, dat in vele streken de naam van het feest ,opklimmen”, n.l. naar de hemel, betekent. Deze gedachte wordt gerealiseerd door de te wijden vrouwen en meisjes op een verhoging te doen verblijven; ze mogen geen contact hebben met de aarde, en daarom worden ze gedragen, of ze gaan over planken, bladeren of boomstammen, die op de grond zijn gelegd. We behoeven er dunkt mij niet aan te twijfelen, of het schommelen is mede een poging om de gedachte te verwerkelijken, dat de meisjes en vrouwen opstijgen naar de hemel om vandaar kracht, gezondheid, voorspoed te halen (verg. Kruyt 2, 579-581; 583-587).

\section{De waringin waaraan de schommel hangt.}

Er zijn nog meer aanwijzingen, die dit vermoeden bevestigen. In de verzamelde berichten lezen we herhaaldelijk, dat de schommel aan een waringinboom moet worden vastgemaakt, of dat men aan de afhangende wortels van deze boom slingert. De Koeboes hebben een nagemaakte waringin bij hun schommelplechtigheid. ${ }^{1}$ ) In meergenoemd opstel over het stamfeest op Midden-Celebes heb ik verteld welk een grote rol de waringin bij deze gelegenheid onder de Zuidtoradjas speelt: men makt een platform in de takken van de boom, en daar verblijft men enige nachten, alsof men in de hemel ware (Kruyt 2, 561-563).

Om het ,hemelse” karakter van de waringin nog meer te doen kennen, wil ik hier meedelen, wat bij de West-toradjas omtrent het geloof in deze boom bestaat. $\mathrm{Bij}$ dit volk had ik gelegenheid een en

1) Van Dongen $(1,277-78)$ zegt: „Wellicht stelt de bamboestok een bringin (waringin), een heiligen boom, d.i. een mensch, voor, met zijn 7 hoofdlichaamsdeelen, $\mathrm{nl}$. het hoofd, de beide armen, de romp boven het middel, de andere helft van de romp en de beide beenen, waaraan tot afwering van kwade geesten de stekelijke versiering is bevestigd, en tot attractie van de te genezen ziel allerlei bloemen”. - Deze ,verklaring” is op zichzelf gezocht, en in verband met de betekenis die de waringin bij zulke gelegenheden heeft, overbodig. 
ander zelf te onderzoeken. Ik twijfel er niet aan, of veel van het hieronder vermelde leeft ook bij andere volken in Indië.

In de eerste plaats herinner ik eraan, dat een veel verbreid geloof is, dat de maanvlek een waringin voorstelt. De West-toradjas zeggen. dat alle waringins op aarde afkomstig zijn van een tak van de maanwaringin. De vruchten van die hemelse boom zijn rijstkorrels en kralen; toen nu een tak ervan afbrak, werden rijstkorrels en kralen op de aarde gestrooid. Bij de verhalen, die vertellen hoe de mensen aan rijst zijn gekomen, zijn er ook die zeggen, dat enige (meestal zeven) aren in een waringin werden gevonden. In Tobakoe van de Koro-groep laat de bevolking zich van de maan-waringin afstammen.

Herhaaldelijk worden offers voor de geesten in de lucht bestemd, aan de voet van een waringin neergelegd; ook gewijde of te wijden voorwerpen worden er een poos lang neergezet. Dit deed men in 't landschap Bada' o.m. met de riddertekens, die de mannen kregen bij het koppensnellersfeest, wanneer ze een mens verslagen hadden. De tekens moesten in aanraking gebracht worden met de hemel om ze levensvatbaar en krachtig te maken.

Een rechtstreekse aanwijzing, dat de waringin gedacht wordt als de weg tussen hemel en aarde vinden we in de verhalen van het volgende type: Een man of een vrouw huwt met een vrouw of een man; die uit de hemel is neergedaald. Op een goede dag krijgt het echtpaar twist, en de hemelling keert boos naar het uitspansel terug. De echtgenoot wil de(n) ander volgen, en hij (zij) gaat daartoe op de top van een waringin zitten, die snel in de hoogte groeit, en zo de aardbewoner in de hemel brengt.

Deze gedachte heeft vermoedelijk ook aanleiding gegeven tot de gewoonte, die bij enige West-toradja-stammen bestaat om op het graf van een overledene een waringintak te planten. Deze waringin moet de levensgeest van de gestorvene naar de hemel terugbrengen, vanwaar hij afkomstig is, terwijl de dodenziel naar het schimmenland onder de aarde gaat.

De waringin als overbrenger van leven en gezondheid spreekt ook uit de gewoonte om aan de kwast waarmee bij verschillende gelegenheden levenswater gesprenkeld wordt, takjes en bladeren van deze boom toe te voegen.

Talrijk zijn de verhalen van mannen die onder een waringin rusten, en uit de boom een stem horen, die hen uitnodigt op te klimmen. Ze kijken op en zien niets bizonders. Dan valt een sirihpruim naar beneden en de stem zegt: „Wrijf uw ogen daarmee in”. Als de man dit 
gedaan heeft, ziet hij in de boom een schitterende woning. Hij klimt naar boven en bevindt zich dan in het gezin van een lucht- of hemelgeest. Als regel huwt hij dan ook met een van de dochters des huizes.

De geest van de waringin maakt de mensen bekend met het genezingswerk der sjamanen, hoe deze middelaars tussen hemel en aarde leven en gezondheid voor hun zieken uit het luchtruim halen. Bij de opleiding en wijding van sjamanen in het landschap Bada' moeten de novieten herhaaldelijk offers neerleggen aan de voet van waringinbomen, waarbij duidelijk uitkomt, dat deze niet bestemd zijn voor een geest die in de boom woont, maar deze offers worden via de boom naar de leven en gezondheid gevende geesten van de lucht gebracht. Zo ook bijv. de offers die bestemd zijn voor het sterrenbeeld Haan (een combinatie van Pleiaden, Gordel van Orion en Sirius), waaraan een overwegende invloed wordt toegekend op het gedijen van de rijst.

Uit het bovenstaande blijkt dunkt mij duidelijk, dat de waringin zijn heiligheid in de eerste plaats ontleend heeft aan de omstandigheid dat hij de hemelboom is, de representant hier op aarde van het rijk van licht en leven in de lucht. En daarom is het alleszins verklaarbaar, waarom men de schommel, waarin men zich naar het rijk in de lucht opheft, aan een waringin hangt. Eerst toen men dit niet meer verstond, is als reden voor de heiligheid op de voorgrond getreden een machtige en gevreesde geest, zoals men zich die in elke grote boom voorstelt te wonen.

De plek waar het feest plaats heeft.

De hemel die men zich op aarde voorstelt te maken is bij de To Seko de woning van het stamhoofd, op Bali de bale agoeng, de hoofdtempel, het forum. Om deze gebouwen heen worden de schommels opgericht, als zovele ladders om de hemel te beklimmen. Dat we hier werkelijk aan een kosmischen hemel hebben te denken blijkt uit het aantal schommels op Bali: vijf, voor elke windstreek één, en één in 't midden, het zenith. Korn deelt geen verdere bizonderheden mede van de versiering van de bale agoeng bij gelegenheid van de oesaba sambah. Vermoedelijk zou daaruit nog een en ander zijn op te maken voor de identificering van dit gebouw met de hemel.

Heel sterk komt dit uit bij de beschreven plechtigheid in Bengkalis. Hier is als hemel een loods gebouwd. De vier metgezellen van de hoofdpersoon, de Djindjang Radja, stellen de vier windstreken voor: ze gaan in de vier hoeken van de loods staan, en daar mag niemand 
tot hen komen; een zwakke voorstelling van de oneindigheid des hemels. Het getal vier en zijn veelvouden, waarmee de kosmos wordt voorgesteld, speelt bij deze gelegenheid een grote rol. Deze hemel is vol licht, want alles wat erin is angebracht, moet geel zijn, de kleur van het licht. In de Djindjang Radja, die geschommeld wordt, hebben we de verpersoonlijking van het ,,vrouwendom” te zien, die schommelend naar de hemel gaat, en vandaar allerlei zegeningen meebrengt.

Ook in het beschreven feest aan het hof van Koetei is duidelijk het stamfeest te herkennen. Wanneer de beschrijver zegt, dat ,the object of this was to drive satan away", kan dit alleen slaan op het indirecte gevolg van de plechtigheid. Het directe is gezondheid en kracht uit de hemel te halen. De zich voortbewegende sterrenwereld wordt voorgesteld door de seriding, de bos jonge arèn- en pinangbladeren moeten, zoals wij uit het stamfeest op Midden-Celebes gezien hebben, de zonnestralen voorstellen. De bos bladeren draait, en de sjamanen draaien met de hemellichamen mee. En als ze moe zijn, benaderen ze de hemel door middel van schommelen. Het schieten met pijlen waarop brandende kaarsjes (in Bocks verhaal) kan wel niet anders betekenen, dan het neerschieten der levenwekkende zonnestralen op de aarde.

\section{De bedoeling van het schommelen.}

Door het schommelen worden de zegeningen des hemels gehaald. Deze gedachte wordt wel heel duidelijk gerealiseerd in hetgeen we van Annam vernamen. Daar wordt als doel van het schommelen gesteld het bereiken van een verzameling geschenken, die in een stellage zijn opgehangen. Elke schommelaar mag één van deze voorwerpen grijpen, en zich toeëigenen. Meer algemeen wordt uitdelen van hemelse gaven gedemonstreerd in het bekogelen van elkaar met pakjes rijst en gebak, zoals we dit van Bengkalis hebben gezien. Dit werpen met etenswaren komt bij verschillende plechtigheden in Indonesië voor, waarbij niet geschommeld wordt; we hebben daarin steeds te zien het uitstorten van de goede gaven des hemels. Bij de Koeboes zullen de eetwaren, die op de weegschaal-schommel worden gelegd, bedoeld zijn als de zichtbare zegen des hemels; dit blijkt vooral dan als slechts één persoon wordt geschommeld.

De beschreven feesten der To Seko, der Tngananners op Bali, en vermoedelijk ook dat ten paleize van den Sultan van Koetei, hebben de bedoeling om niet alleen de gezondheid en de vruchtbaarheid van de mensen te bevorderen, maar ook om de veestapel te doen toenemen, 
en de gewassen te doen gedijen. Heel duidelijk is dit te zien op het feest in Tnganan. Het eerste dat op de schommel wordt geplaatst is een bak, waarin alle voor den mens nuttige gewassen geschikt zijn. Deze bak, de komaligi, wordt door de schommel naar de hemel gevoerd om gezegend te worden, en versterkt daaruit terug te keren. Op dit feest worden voor de vergaderloods der jongelingen allerlei vruchtbomen geplant, en daartussen wordt geofferd. De bedoeling kan wel niet anders zijn, dan door deze plechtigheid te bewerken, dat aan de vruchtbomen nieuw leven wordt toegevoerd, opdat ze rijkelijk vrucht dragen zullen. De veestapel wordt bedacht in het voornaamste dier ervan, de karbouw. Het beschreven rituele stelen van buffelvlees moet te kennen geven de overvloed van vlees die er zal zijn; het behangen der beide jongens met buffelvlees en de geslachtsdeelen van deze dieren is wel niet anders op te vatten dan als een middel om de vruchtbaarheid der dieren te bevorderen, opdat ze veel jongen zullen werpen.

Hoofdzaak op het feest blijft de mens. Alle handelingen op het feest moeten dienen om de jonge mensen, die later met elkaar zullen huwen, en nakroost zullen voortbrengen, daartoe te sterken en geschikt te maken. De meisjes gaan deze zegen zelf op de schommel in de hemel halen.

Wanneer we nu de bedoeling van de overige plechtigheden nagaan, zien we dat deze niet van zo algemene aard zijn als de pas besproken drie feesten. Schommelen wordt bij verscheiden volken gedaan voor een bepaald onderdeel van de voorspoed der mensen. Het is begrijpelijk, dat de natuurmens zijn hoogste geluk ziet in een welgeslaagde rijstoogst. Zo zien we dan, dat onder enkele Toradja-stammen en Dajak-volken het schommelen in 't bizonder wordt toegepast om een zegen voor de rijst uit de hemel te verwerven. Die zegen stellen de Dajaks zich in tastbare vorm voor, wanneer onder de opwinding van het schommelen kleine steentjes, bosjes haar en rijstkorrels op de grond vallen, en zorgvuldig door de feestgangers worden opgeraapt. Met de steentjes en het haar zijn de geconcentreerde gezondheid en levenskracht der mensen bedoeld; de rijstkorrels zijn de ,ziel” van het gewas, die de oogst doet gelukken.

De liederen of litanieën, die op de schommel worden gezongen, beschrijven alle een schitterend geslaagde oogst, als een profetie, hoe de nieuwe oogst zal zijn. Ook bij de Boeginezen moet de voornaamste bedoeling van de schommelfeesten zijn een zegen voor het gewas uit de hemel te halen. Maar duidelijk is daarmee de wens verbonden om 
de vruchtbaarheid der mensen te beinvloeden. Trouwens men scheidt in Indonesië de vruchtbaarheid van mens, dier en plant niet van elkaar; de een staat in nauw verband met de ander; de hemelzegen beinvloedt alles wat leeft op aarde.

We hebben tot nu toe gezien, en we zullen dit ook voor het vervolg opmerken, dat het schommelen een rituele handeling is, een voorstelling van het halen van de zegen uit het rijk van licht en leven. Maar daarnaast treedt ten opzichte van de rijstbouw ook een magisch element aan de dag. We lezen toch van enkele Toradja-stammen, van de Karo-bataks en van de Javanen, dat daar bij voorkeur geschommeld wordt in de tijd dat de vrucht van de rijst aan het uitkomen is, en men hoopt door het schommelen de aar lang en zwaar te maken. Ik geloof niet, dat we hier een kwestie hebben van twee stadia van denken, waarvan we zouden kunnen zeggen, dat het ene ouder zou moeten zijn dan het andere. Herhaaldelijk komt het voor, dat aan dezelfde handelingen zowel een godsdienstige als een magische zin gehecht wordt. Ook hierin is het een nauwelijks van het ander te scheiden. De zegen des hemels waarop gehoopt wordt, openbaart zich in lange zware aren. Daar waar de nadruk meer valt op de gave des hemels, is het schommelen middel om die gave deelachtig te worden; denkt de mens meer in dynamistische richting, dan zal hij in het schommelen het magisch beinvloeden van het gewas aanvoelen. Een in hoofdzaak magische bedoeling heeft ook het schommelen bij de Kai-papoeas; ook hier moet het schommelen dienen om de knollen groter te doen worden, waartoe ook moet dienen het roepen met name van de gewassen.

Sommige plechtigheden waarbij geschommeld wordt, dienen uitsluitend tot versterking van de mens. Deze gedachte komt vooral tot uiting in het schommelen van moeder en zuigeling. Dat dit schommelen inderdaad bedoeld is om het kind in de hemel te brengen teneinde het te doen delen in de ongestoorde gezondheid en het krachtige leven, die daar te vinden zijn, blijkt uit het hele verhaal ervan in het Boeginese heldenepos, de La Galigo. Dit schommelen van kleine kinderen vinden we bij de Karo-bataks. Dat het versterken van de nog zwakke zuigeling de bedoeling van het schommelen op de weegschaal der Koeboes is, mogen we opmaken uit de omstandigheid, dat Van Hasselt zag, dat een moeder zich met een zuigeling zat te schommelen, en dat Schebesta het schommelen zag toegepast bij een ziek kind. Het schommelen op de weegschaal van volwassenen, wanneer dezen voor de eerste maal in het huwelijk treden, zullen we dus hebben op te vatten als een uitgesteld schommelen van de zuigeling. Dit 
blijkt ook uit hetgeen de menschen er zelf van vertellen, nl. dat de malim (doekoen) bij deze gelegenheid zijn loon ontvangt voor hetgeen hij gedaan heeft om bruid of (en) bruidegom gezondheid en kracht bij te brengen, toen ze nog kinderen waren. In dit licht gezien wint het vermoeden aan waarschijnlijkheid, dat de etenswaren die op de weegschaal worden gelegd om hem in evenwicht te brengen, de zichtbare zegeningen uit de hemel zijn. Wanneer van Dongen als verklaring van dit schommelen opgeeft, dat het moet dienen om het paar een gelukkig leven deelachtig te doen worden, dan is dit zeker juist (Van Dongen 1, 285). Minder juist acht ik het, dat het wegen en schommelen van moeder en kind, dat Schebesta noemt, zou zijn het nemen van ,een proef op de som”, teneinde te weten of de ziekte veroorzakende krachten tevreden zijn met het offer dat op de andere schaal gelegd is, en zij dus zullen aflaten het kind verder te kwellen. Van Dongen heeft de nadruk op het wegen gelegd, waartoe aanleiding is door de naam timbang ,wegen”, die de Koeboes zelf aan deze plechtigheid geven. Het is echter een gewoon verschijnsel, dat een feest aangeduid wordt met de naam van een onderdeel ervan, en vaak nog een onbelangrijk onderdeel. Hoe de Koeboes ertoe gekomen kunnen zijn om van de schommel ,een soort weegschaal” te maken komt beneden nog ter sprake.

\section{De schommel gaat over in de wieg.}

Een gevolg van de gewoonte om de zuigeling te schommelen teneinde hem de hemelse gaven van gezondheid en kracht deelachtig te doen worden, is het gebruik van de wieg. De gewoonte om een zuigeling in een opgehangen saroeng te leggen en het daarin wat heen en weer te schommelen om het in slaap te krijgen is algemeen in de Archipel. Maar het gebruik van een wieg, d.i. een bak die aan vier touwen in de hoeken aan een veerkrachtige lat wordt opgehangen, en daaraan op en neer wordt bewogen, is niet algemeen. Van vele Dajakstammen in Nederlands Borneo wordt verteld, dat ze geen wieg hebben; de zuigeling brengt het grootste deel van zijn leven door in de bah anak, het draagbakje (Elshout, 198). Bij de Dajakstammen onder wie Nieuwenhuis reisde, kent men de wieg niet; het kind wordt wel in een opgehangen saroeng gelegd (Nieuwenhuis I, 62). Van al deze stammen wordt ook niet het rituele schommelen vermeld. Van de Doesoen-dajaks in Brits Noord Borneo daarentegen, waar het schommelen gebruikelijk is, zoals we hebben gezien, lezen we: „The 
cradle consists of the hollowed trunk of a tree, suspended by strings from the ceiling. There are no circumstances connected with the dressing or cradling of children tending in any way to modify the shape of the body" (Ling Roth I, 99).

We kunnen echter geen algemene regel maken en zeggen: Waar men het rituele schommelen kent, heeft men ook de wieg; en andersom: waar niet geschommeld wordt, bestaat de wieg niet. In dit opzicht is een overzicht van de aanwezigheid van de wieg op Celebes leerrijk. Makassaren en Boeginezen gebruiken hem; bij de eerste heet hij toëng, bij de laatsten todjang.

„Op Boeton kent men de schommelwieg (kaboë), vertelt Dr. Cense; die is echter alleen bij den hoogsten stand, de Kaoemoc, in gebruik. Het is een binnenshuis aan touwen opgehangen bak, vrij laag boven de vloer. Men plaatst de kinderen op de kaboë, wanneer ze 42 dagen oud zijn; ook de moeder en soms nog andere personen nemen er soms op plaats. Men wiegt de bak dan zachtjes heen en weer. $\mathrm{Na}$ het hier genoemde tijdstip kan dit wiegen ten allen tijde gebeuren. Er vinden echter geen bijzondere ceremonieën bij plaats".

Van de Zuid-toradjas, waarbij het ritueel schommelen algemeen bekend is, weten we, dat ze geen wieg hebben (A. C. Kruyt 1, 134). In het Galoempangse daarentegen heeft men de wieg, poë, wèl, terwijl ik daar niets van het ritueel schommelen gemerkt heb. De wieg wordt hier met veel voorzorgen van hout gemaakt; de vervaardiger mag onder zijn werk niet praten, anders zal het kind veel huilen; vreemdelingen mogen niet komen kijken; als de wieg klaar is, wordt de kam van een haan afgesneden, en met het daaruit druipende bloed wordt de wieg bestreken; de haan zelf mag niet worden geslacht; de vogel blijft leven als plaatsvervanger van het kind. Eerst wanneer het een maand oud is, mag de zuigeling in de wieg worden gelegd.

Gaan we verder dan zien we, dat de To Seko, die zoveel aan ritueel schommelen doen, geen kinderwieg gebruiken, ja ze verklaren bang te zijn om een kind in een wieg te leggen, omdat het ritueel schommelen alleen gedaan mag worden onder het brengen van veel offers; zonder die offers is schommelen gevaarlijk voor het leven en de gezondheid; voor een zuigeling kunnen die offers niet gebracht worden, dus mag het niet in een wieg. Dezelfde vrees om het kind in een wieg te leggen vinden we bij de stammen der West-toradjas, die geen wieg kennen, nl. de Lore-, de Rampi'- en de Koro-groepen. De Kaili- en Sigi-groepen van dit volk gebruiken allen de wieg. Bij de groepen tussen die twee in (Koelawi- en Pakawa-groepen) wordt de 
wieg gebruikt door hen, die dit van oudsher gewend zijn; bij de anderen niet; dit is het gevolg van gemengde huwelijken tussen hen die de wieg hebben, en hen die hem niet kennen ; maar de laatsten zullen er dan ook niet aan denken een kind in een wieg te leggen.

$\mathrm{Bij}$ de Oost-toradjas is de wieg algemeen in gebruik met uitzondering van de To Wana, een volksdeel, dat altijd in een hoek is geduwd, en dat daardoor de algemeene ontwikkeling van dit volk niet heeft meegemaakt. Bij de Oost-toradjas worden dezelfde voorschriften bij het maken van een wieg genomen, als van Galoempang is vermeld. Ook hier mag de zuigeling pas in de wieg worden gelegd, als het enige dagen oud is.

Nog meer naar het Oosten van Celebes gaande vinden we de wieg niet bij de To Loinang, maar wel in Balantak en de Banggai-archipel. Bij het maken van de wieg worden ook hier allerlei voorschriften in acht genomen, en het kind mag pas enige tijd, soms pas na een maand, in de wieg worden gelegd; hier en daar wordt gewacht op een ,goede dag".

In de Minahassa kent men de wieg nergens. De geschiedenis van de wieg op Celebes bewijst wel, dat het gebruik van wiegen en het ritueel schommelen twee dingen zijn, die hier naast elkaar staan, ofschoon het eerste uit het tweede moet zijn voortgekomen. Voor Celebes is het vrij duidelijk, dat het gebruik van de wieg verband houdt met de penetratie van de Boeginese en (of) Loewoe'se invloed. Overal waar deze is aan te wijzen, wordt de wieg gevonden. Dat men dit meubel door Loewoe'se invloed heeft leren kennen wordt uitgesproken in een overlevering, die het ontstaan van het vorstenhuis van Waiboenta in Loewoe' verklaart. De eerste vorst van dat land nam. was uit de hemel neergedaald. Hij huwde met een meisje dat uit een bamboe was voortgekomen. Het echtpaar kreeg een kind. Maar op zekere dag ontstond er twist tussen hen over het reinigen van de faeces van de kleine. Boos klom de vader naar de hemel terug, waarheen zijn vrouw hem volgde. Het kind begon erbarmelijk te huilen, omdat het de moeder miste. De rijksbestierder (baloilo) wist niet wat hij met het kind moest aanvangen. Toen We lele aloeng, de moeder, echter het geschrei van het kind hoorde, keerde ze uit de hemel op aarde terug en leerde den baloilo een wieg maken, en vertelde hem hoe hij het kind moest wiegen.

De voorzorgen, die bij het maken van een wieg worden genomen, en de omstandigheid dat het kind er pas in gelegd mag worden, als het enige dagen oud is, kenmerken het wiegen nog als een ritueele 
handeling. Het kind moet eerst bewijzen levensvatbaarheid genoeg te bezitten om het gevaar dat aan elke rituele handeling verbonden is, weerstand te kunnen bieden. Of we nu uit de geschiedenis van de wieg op Celebes mogen besluiten, dat de overgang van schommel tot wieg bij de Boeginezen heeft plaats gehad, is zeer de vraag. Ook onder dit volk kan de wieg zijn gekomen, reeds afgescheiden van de schommel.

Het verdient wel opmerking, dat we niets van het magisch element in het gebruik van de wieg terugvinden. Zo ergens dan zouden we hier verwachten, dat men het kind wiegt (schommelt) om het spoedig groot te doen worden. In plaats daarvan vinden we juist vrees voor de wieg bij hen, die er door de ene of andere oorzaak niet van ouderher aan gewend zijn. Dit is, zoals al gezegd is, mede een bewijs dat het wiegen een rituele handeling is gelijkstaande met het ritueel schommelen.

Ik beschik niet over de nodige gegevens om aan te tonen hoe het met 't gebruik van de wieg op Java staat. Het is ook mogelijk dat hij hier en daar op de kleine Soenda-eilanden en in de Grote Oost gevonden wordt. Evenwel in verband met de enkele gegevens, die mij ter beschikking staan, vermoed ik dat de wieg in het Oosten van de Archipel niet gevonden wordt. Op de eilanden waarvan in de literatuur op dit punt iets gezegd wordt, bestaat de wieg niet (o.m. Geurtjes, 363; Neuhauss III, 27 en 254; het bed van de zuigeling is hier een „Netzsack ohne jede Unterlage”). Dit alles doet ons besluiten, dat de wieg van vreemde oorsprong is, en dat hij niet altijd samengaat met het schommelen.

Waar het schommelen niet 't kind in 't bizonder geldt, moet het dienen om volwassenen, en speciaal meisjes en vrouwen, gezondheid en kracht toe te voeren, opdat ze door het voortbrengen van kinderen de stam in stand kunnen houden. Waar de sjamaan zich al schommelend in trance brengt, kunnen wij het schommelen in dit verband niet anders verstaan, dan dat hij door zijn bezoek aan de hemel een ander mens geworden is, toegerust met hemelse krachten, die hij den medemens ten goede laat komen.

\section{Is het schommelen Indonesisch of overgenomen?}

Tenslotte moeten wij ons nog bezig houden met de vraag of het ritueel gebruik van de schommel van oorsprong Indonesisch is, dan wel of het overgenomen is van anderen. Dat natuurvolken in het alle- 
daagse schommelen iets hebben gezien, waardoor ze meenden de groei van het gewas magisch te kunnen beinvloeden, behoeft niet overgenomen te zijn. Dit is echter iets anders dan het ritueel schommelen, waardoor contact wordt gezocht met de bovenwereld. Het zoeken van dit contact, teneinde de zegeningen des hemels deelachtig te worden is zeker Indonesisch, maar het gebruik van de schommel als een middel om die anraking te krijgen, is vermoedelijk niet inheems maar overgenomen. Opmerkelijk is evenwel, dat wij het vinden bij primitieve volken als de To Seko en de Koeboes.

Als we ons de vraag voorleggen, of men het schommelen elders kan hebben gekend, maar het gebruik ervan heeft vergeten, dan kan alleen met enige zekerheid worden geantwoord ten opzichte van de Oost- en de West-toradjas. En dan meen ik te kunnen zeggen, dat ze het ritueel schommelen nimmer hebben gekend. Waar bij het stamfeest van deze volken vele ceremoniën in gebruik zijn, die de aanraking met de bovenwereld heten te bewerkstelligen, zou het wonderlijk zijn, dat het schommelen verloren zou zijn gegaan, als men het eens had gekend. Toch blijft het vreemd, dat het schommelen bij de To Seko een grote rol speelt bij het stamfeest, terwijl de Toradja-stammen in het Rongkong- en Karama-stroomgebied, met welke zij niet alleen de naam van het feest, maar ook veel gebruiken gemeen hebben, het niet kennen.

Wat de Koeboes betreft meen ik een aanwijzing te hebben, die wijst in de richting van overnemen van het schommelen. We hebben namelijk gezien, dat de inwoners van Tnganan Turkse schommels gebruiken, waarbij de illusie, dat men naar de hemel opvaart, nog sterker wordt, dan bij de gewone schommel. Maar hoe weifelend wij ook mogen staan tegenover de vraag of het ritueel schommelen een oorspronkelijk indonesisch gebruik is, dat de Turkse schommel op Bali van vreemde oorsprong is, zal wel niemand betwijfelen. Nu kan ik in de ,soort van weegschaal" bij de Koeboes niet anders zien dan een mislukte poging om de Turkse schommel na te bootsen. Het wegen van personen is zó on-Indonesisch, dat deze gewoonte op zichzelf al van vreemde oorsprong zou moeten zijn.

Een overzicht van het ritueel schommelen geeft Sir James G. Frazer in het derde deel van zijn Golden Bough ,The dying God”, Note B. Swinging as a magical rite, $3 \mathrm{~d}$ edition, p. 277-285). Uit dit overzicht zien we hoe algemeen verspreid het ritueel schommelen over de wereld is. Frazer meent terecht, dat het niet mogelijk is om alle gevallen op dezelfde wijze te verklaren. Hij zoekt voornamelijk een 
magische zin in het schommelen, en deze zit ook werkelijk in vele gevallen, die hij noemt. Maar aan Frazer schijnt de godsdienstige zin van andere gevallen te ontgaan. Waar de magische bedoeling van het schommelen niet voor de hand ligt, ziet Frazer in het schommelen een middel om boze geesten te verjagen. Het zoeken van contact met de bovenwereld merkt hij in 't schommelen niet op.

Toch treedt dit laatste duidelijk aan de dag bij het schommelen in Voor-Indië, het land waarheen onze blikken zich het eerst richten, als er van overnemen gesproken wordt. „About the middle of March, vertelt Frazer, the Hindoos observe a swinging festival of a different sort in honour of the god Krishna, whose image is placed in the seat of a cradle or a swing and then, just when the dawn is breaking, rocked gently to and fro several times. The same ceremony is repeated at noon and at sunset. In the Rigveda the sun is called by a natural metaphor ,the golden swing in the sky", and the expression helps us to understand a ceremony of Vedic India. A priest sat in a swing and touched with the span of his right hand at once the seat of the swing and the ground. In doing so he said, ,The great lord has united himself with the great lady, the god has united himself with the goddess”. Frazer zegt ter verklaring: „Perhaps he meant to indicate in a graphic way that the sun had reached that lowest point of its course where it was nearest to the earth". In dit constateren van een feit wordt echter niet verklaard waarom geschommeld wordt. We zien hier een sprekend voorbeeld van het in contact brengen van de aarde met de hemel door schommelen.

Om nu weer op het ritueel schommelen in Indonesië terug te komen heb ik de indruk, dat dit inderdaad van vreemde oorsprong is, ofschoon ik er geen bewijzen voor heb gevonden, en de voorstelling omtrent het zoeken van aanraking met de bovenwereld, de hemel, waarvan het schommelen deel uitmaakt, echt Indonesisch is. We hebben dan het schommelen te beschouwen als een pendant van het dansen. Als de natuurmens in zijn voorstelling een lange weg op aarde heeft af te leggen, om bijv. de ziel van een overledene naar het schimmenland onder de aarde te brengen, of om een machtigen geest te bezoeken, die op een hoge berg of een ander punt op aarde troont, en hij wil die lange tocht in de werkelijkheid overbrengen, dan komt hij er vanzelf toe om almaar in de rondte te lopen, en in woorden (zang) te kennen te geven, wat hij doet, en met welk doel de tocht gedaan wordt. En omdat dit ,lopen” gestileerd wordt en rythmisch geschiedt, noemen wij het ,dansen”. Wil de natuurmens nu in zijn 
voorstelling naar de hemel om er dingen van de aarde te brengen, die hij wil laten zegenen, of om vandaar zegeningen, die men van de in de bovenwereld (hemel) wonende machten afsmeekt, op aarde uit te storten, dan kan de tocht opwaarts niet beter veraanschouwelijkt worden, dan door zich in een schommel naar boven te werken. Wat men doet, en wat men beoogt, wordt in liederen of litanieën, die bij het schommelen gezongen worden, te kennen gegeven.

Zo zouden we kunnen besluiten: Wat de dans voor den natuurmens is om op aarde gelegen doeleinden te bereiken, is het schommelen om die dingen te verwerven, die alleen in de bovenwereld, in de hemel, de bron van licht, leven, gezondheid, kracht, te krijgen zijn.

\section{Aangehaalde boeken en tijdschriftartikelen.}

Carl Bock. The Headhunters of Borneo. London 1882.

C. J. van Dongen 1, De Koeboes in de ond.afd. Koeboestreken der Residentie Palembang, Bijdragen 63, 1910.

idem 2, Een en ander over de Koeboes naar aanleiding van Prof. P. P. Schebesta's publicaties over dit volk. Bijdragen 88, 1931.

J. M. Elshout. De geneeskunde der Kenja-dajak in Centraal-Borneo in verband met hun godsdienst. 1923.

H. E. D. Engelhard, Mededeelingen over het eiland Saleyer. Bijdragen 32, 1884.

Sir James G. Frazer, The Golden Bough III, The dying God, 3d. edition. London.

idem. Aftermath, a supplement to the Golden Bough. London 1936.

H. Geurtjens. Uit een vreemde wereld. 's-Hertogenbosch 1921.

N. Graafland. De Minahassa. 2e druk.

J. S. G. Gramberg. De Troeboekvisscherij. Tijd. Bat. Gen., dl. 24. 1877.

A. L. van Hasselt. Volksbeschrijving van Midden-Sumatra. Leiden 1882.

W. Kaudern. Games and Dances in Celebes. Results of the Authors expedition to Celebes 1917-20, dl. IV. Göteborg.

V. E. Korn. De dorpsrepubliek Tnganan Pagringsingan. Santpoort 1933 
A. C. Kruyt 1, De Toradjas van de Sa'dan-, Masoepoe- en Mamasarivieren. Tijd. Bat. Gen., dl. 63, 1923-24, 81-175, en 259-401. idem 2, Het Stamfeest op Midden-Celebes, Tijd. Bat. Gen. 75, 1935, $550-604$.

J. Kruyt 1, De Boea' en eenige andere feesten der Toradjas van Rante pao en Ma'kale. Tijd. Bat. Gen., dl. 60, 1921, 45-77 en $161-186$.

idem 2, Het ma'boea' en de tatoeage in Seko (Midden-Celebes). Bijdragen, dl. 76, 1920, 235-257.

H. Ling Roth. The Natives of Serawak and British North Borneo. London 1896.

Edwin Loeb. Mentawei myths. Bijdragen 85, 1929.

B. F. Matthes 1. Bijdragen tot de ethnologie van Zuid-Celebes. 's-Gravenhage 1875 .

idem 2. Boegineesch-Nederlandsch Woordenboek.

idem 3. Einige Eigentümlichkeiten in den Festen und Gewohnheiten der Makassaren und Buginesen. Leiden 1884.

idem 4. Beknopt verslag mijner reizen in de binnenlanden van Celebes in de jaren 1857 en 1861. Verzameling van Berigten betreffende de Bijbelverspreiding, 96-99.

idem 5. Verslag van een uitstapje naar de Oosterdistrikten. Jaarboekje Celebes 1865. Makassar 1865.

Mededeelingen betreffende eenige Mandharsche landschappen. Bijdragen 62, 1909.

R. Neuhauss. Deutsch Neu Guinea III. Ch. Keysser. Aus dem Leben der Kai-leute. Berlin 1911.

Nguyen van Huyen. Les Chants alternés des garçons et des filles en Annam. Paris 1934.

A. W. Nieuwenhuis. In Centraal Borneo. Leiden 1900.

J. Perham. Manangism in Borneo. Journal of the Straits Branch of the Royal Asiatic Society, 1887.

J. A. Th. Schwartz. Tontemboansche Teksten II, vertaling. Leiden 1907.

Sir Spencer St. John. Life in the forest of the far East. London 1862. 
J. A. van Staveren. De Rokka's van Midden-Timor. Tijd. Bat. Gen., dl. 57, 1915.

H. Sundermann. Religiöse Vorstellungen und darauf sich gründende Sitten und Gebräuche der heidnischen Dajak auf Borneo. Bijdragen, dl. 76, 1920.

S. W. Tromp. Uit de Salasila van Borneo. Bijdragen 37, 1888.

P. te Wechel. Erinnerungen aus den Ost- und West-Dusun-Ländern (Borneo), in besonderen Hinblick auf die animistische Lebensauffassung der Dajak. Int. Archiv f. Ethnografie 22, 1915. 